\title{
TRÁFICO ATLÂNTICO, MERCADO COLONIAL E FAMÍLIAS ESCRAVAS NO RIO DE JANEIRO, BRASIL, c. 1790-c.1830
}

\author{
The slave trade, colonial markets and \\ slave families in Rio de Janeiro, \\ Brazil, ca. 1790-ca. 1830
}

Manolo Florentino*

\begin{abstract}
RESUMO
O presente artigo se utiliza do The trans-Atlantic slave trade: a dataset on-line e de outras fontes para, a partir do caso do Rio de Janeiro, buscar redefinir algumas posições clássicas da historiografia brasileira acerca das relações entre o tráfico de africanos, o mercado colonial e algumas práticas familiares forjadas pelos próprios escravos.
\end{abstract}

Palavras-chave: tráfico atlântico; mercado colonial; famílias escravas.

\begin{abstract}
The article below utilizes this databank and other sources relating to the slave trade in Rio de Janeiro in order to redefine some classic positions in Brazilian historiography regarding relationships between the Africans traffic, the colonial market and certain family practices created by the slaves themselves.
\end{abstract}

Keywords: Atlantic slave trade; colonial markets; slave families.

* Professor do Departamento de História da Universidade Federal do Rio de Janeiro. Com pequenas modificações, o presente trabalho foi publicado sob o título de The slave trade, colonial markets and slave families in Rio de Janeiro, Brazil, ca. 1790-ca. 1830. In: ELTIS, David; RICHARDSON, David (Eds.). Extending frontiers. Essays on the new transatlantic slave trade database. New Haven \& London: Yale University Press, p. 275-312, 2008. 


\section{Introdução}

Quatro entre cada dez escravos africanos desembarcados nas Américas foram importados pelo Brasil e apenas no século XVIII aportaram na América portuguesa menos negros do que em outra região do Novo Mundo. Apesar disso, a história do comércio negreiro para o Brasil é, talvez, a menos conhecida entre os grandes tráficos da Época Moderna, o que não raro enseja a apresentação de soluções algo artificiais a intrincados problemas teóricos e de interpretação. Quando menos por isso, é extremamente auspiciosa uma iniciativa como a que resultou no The trans-Atlantic slave trade: a dataset on-line (http://www.slavevoyages.org/tast/assessment/estimates. faces, de agora em diante TSTD 2), o qual busca prover os especialistas e interessados em geral de instrumentos que deem conta da história da diáspora africana para as Américas ${ }^{1}$. O presente estudo se utiliza deste banco de dados e de outras fontes para, a partir do caso do Rio de Janeiro, buscar redefinir algumas posições clássicas da historiografia brasileira acerca das relações entre o tráfico de africanos, o mercado colonial e algumas práticas familiares forjadas pelos próprios escravos ${ }^{2}$.

De acordo com alguns autores, o comércio negreiro era uma empresa de caráter essencialmente metropolitano. A reposição física dos cativos dar-se-ia externamente à sociedade colonial, não somente porque de fora dela viria o agente produtivo maior - o escravo -, mas também porque seriam externos os agentes mercantis que viabilizavam o comércio de africanos ${ }^{3}$. Tal approach teórico é, na verdade, a consequência anunciada de modelos

1 ELTIS, David; BEHRENDT, Stephen; RICHARDSON, David; KLEIN, Herbert. The Trans-Atlantic Slave Trade: a Dataset on CD-ROM, 1999 (daqui por diante TSTD 1). ELTIS, David; BEHRENDT, Stephen; RICHARDSON, David; FLORENTINO, Manolo. The trans-Atlantic Slave Trade: a Dataset On-Line (http://www.slavevoyages.org/tast/assessment/estimates.faces, daqui por diante TSTD 2).

2 Alguns dos argumentos seguintes aparecem em FLORENTINO, Manolo. Em costas negras: uma história do tráfico de escravos entre a África e o Rio de Janeiro (séculos XVIII e XIX). São Paulo: Companhia das Letras, 1997; A paz das senzalas (familias escravas e tráfico atlântico, Rio de Janeiro, c. 1790-c. 1850). Rio de Janeiro: Civilização Brasileira, 1997, escrito em colaboração com José Roberto Góes; e $O$ arcaísmo como projeto. Rio de Janeiro: Civilização Brasileira, 2001, escrito em colaboração com João Luís Ribeiro Fragoso.

3 GORENDER, Jacob. O escravismo colonial. São Paulo: Ática, 1978, p. 120, 208, 211 e 544; e NOVAIS, Fernando A. Portugal e Brasil na crise do antigo sistema colonial (1777-1808). São Paulo: Hucitec, 1983, p. 104-105. 
explicativos que afirmam a mais completa atrofia dos mercadores coloniais, modelos nos quais os plantadores aparecem no topo da hierarquia das sociedades do Novo Mundo. Mesmo quando se aponta para a possibilidade de parcos níveis de acumulações endógenas, exclui-se o setor mercantil.

Ao menos para o caso do Brasil, é possível rever a ideia segundo a qual a reprodução externa da escravidão funcionava como um potente mecanismo de desacumulação ${ }^{4}$. Sabe-se que por quase meio século - de 1810 a 1850 - as elites brasileiras puderam resistir às pressões britânicas pelo fim do tráfico, o que só pode ser compreendido se tomarmos o comércio negreiro como um importante circuito interno de acumulação de riqueza, detentor de grande autonomia frente ao capital mercantil internacional. Os lucros gerados pelo tráfico transformaram os mercadores de escravos na mais importante fração da elite brasileira, posição que lhe facultava influenciar decisivamente os destinos do Estado.

Não gratuitamente, de passagem pelo Brasil na primeira metade do século XIX, certo negociante europeu observou que os homens livres criavam longas unhas para demonstrar sua distância em relação ao mundo do trabalho ${ }^{5}$. Comprar e vender homens contribuía para que, aos olhos de grande parte da sociedade, os escravos não passassem de meros objetos, dos quais se podia dispor da maneira que fosse. Jamais se pôde, porém, reduzir qualquer homem escravizado à condição de mero instrumentum vocale. Os cativos sempre buscaram criar e recriar meios de afirmação cultural. Para tanto, ao lado daquilo a que muitos frequentemente se referem - as constantes fugas ou as compras da liberdade, por exemplo -, a constituição de famílias talvez tenha desempenhado um papel central. Esta possibilidade justifica o estudo das relações entre o tráfico negreiro e algumas das práticas culturais que ensejavam a socialização parental dos cativos e ajudavam a afirmar a sua identidade social.

4 Para um ponto de vista contrário a este, cf. FLORENTINO, Manolo. Em costas negras: uma história do tráfico de escravos entre a África e o Rio de Janeiro (séculos XVIII e XIX). São Paulo: Companhia das Letras, 1997. Outra contribuição é a de ALENCASTRO, Luiz Felipe de. O trato dos viventes. Formação do Brasil no Atlântico Sul. São Paulo: Companhia das Letras, 2000.

5 REIS, João J. A morte é uma festa. Ritos fúnebres e revolta popular no Brasil do século XIX. São Paulo: Companhia das Letras. 1995, p. 38. 


\section{Tráfico de escravos e escravidão no Rio de Janeiro, 1790-1830}

Aferir semelhantes ideias a partir do caso do Rio de Janeiro encontra sua justificativa inicial no fato de que semelhante região constituía um exemplo clássico de sociedade escravista colonial. Cento e setenta mil pessoas habitavam a capitania em 1789 - metade das quais escravos. Em 1824, estes alcançavam mais de 150 mil almas - quase o dobro da cifra de $1789^{6}$. Contínuos desembarques de africanos sustentavam semelhante crescimento, em quantidades anuais que saltaram de cerca dez mil em fins do século XVIII para quarenta mil nos últimos cinco anos da década de $1820^{7}$.

É instigante a antiga observação de Moses Finley, segundo a qual é escravista - e não meramente possuidora de escravos - toda sociedade cuja elite se reproduz mediante a exploração do trabalho dos cativos ${ }^{8}$. Longe de se apresentar tautológico, semelhante procedimento remete ao fato de que diferenciar os homens livres entre si seria o fim último do escravismo. Ora, se a escravidão reproduzia continuamente a elite colonial, e se esta se recompunha e fazia crescer seus estoques de cativos, sobretudo por meio do tráfico atlântico, é forçoso concluir ter sido o fim último da migração compulsória de africanos a reprodução do topos social da elite da América portuguesa. Em outras palavras, ao incremento dos desembarques de africanos correspondia o aumento da diferenciação socioeconômica entre os homens livres.

No Rio de Janeiro, nunca menos de $84 \%$ de todos aqueles que, ao morrer entre 1789 e 1832, abriam inventários post-mortem eram donos de pelo menos um cativo. Semelhante dado indica um alto nível de dissemina-

6 NUNES, Antônio Duarte. Memórias públicas e econômicas da cidade de São Sebastião do Rio de Janeiro para o uso do Vice-rei Luiz de Vasconcellos por observação curiosa dos annos de 1779 até o de 1789. In: Revista do Instituto Histórico e Geográfico Brasileiro, n. 48, p. 29, 1884, e também IBGE. Estatísticas Históricas do Brasil. Rio de Janeiro: IBGE, 1986, v. 3, p. 30.

7 Tal período (1790-1830) se insere, grosso modo, nos anos em que o tráfico para o Brasil foi ao mesmo tempo livre a todos os habitantes e, ademais, legal. De fato, a Coroa portuguesa reconheceu a debilidade comercial metropolitana para financiar o tráfico no ritmo requerido pela demanda colonial quando, em 1758, decretou livre o comércio de escravos a todos os súditos do império - cf. GOULART, Maurício. A escravidão africana no Brasil (das origens à extinção do tráfico). São Paulo: Alfa-Ômega, 1975, p. 192.

8 FINLEY, Moses I. Escravidão antiga e ideologia moderna. Rio de Janeiro: Graal, 1991, passim. 
ção social da propriedade escrava e, em princípio, poderia negar a máxima de Finley - afinal, se tantos tinham acesso a escravos, a propriedade destes por si só não se constituiria em elemento capaz de diferenciar os homens livres entre si. Entretanto, o amplo acesso de diversos segmentos sociais aos escravos não encobria a enorme concentração. Deste modo, entre 1789 e 1808 , cerca de $60 \%$ dos senhores de escravos do Rio detinham ao menos dez cativos, vinculados, sobretudo, à produção de alimentos que abastecia as grandes propriedades e os núcleos urbanos, mas também ao artesanato e às atividades de ganho e domésticas. Por seu turno, os estabelecimentos rurais e urbanos com mais de 20 cativos estavam em mãos de cerca de $15 \%$ dos proprietários, uma elite que possuía $45 \%$ dos cativos - as pequenas unidades produtivas, ao invés, detinham apenas um entre cada quatro escravos, tal como pode ser observado através da tabela 1 .

TABELA 1 - VARIAÇÃO (\%) DA POSSE DE ESCRAVOS DE ACORDO COM AS GRANDES FAIXAS DE TAMANHO DE PLANTÉIS DOS MEIOS RURAL E URBANO DO RIO DE JANEIRO, 1789-1832

\begin{tabular}{l|c|c|c|c|c|c|c|c}
\hline & \multicolumn{4}{|c|}{$1789-1808$} & \multicolumn{4}{|c}{$1810-1832$} \\
\cline { 2 - 9 } & $\begin{array}{c}\% \text { de } \\
\text { proprie- } \\
\text { tários }\end{array}$ & $\begin{array}{c}\% \text { de } \\
\text { escra- } \\
\text { vos }\end{array}$ & $\begin{array}{c}\# \text { de } \\
\text { proprie- } \\
\text { tários }\end{array}$ & $\begin{array}{c}\# \text { de } \\
\text { escra- } \\
\text { vos }\end{array}$ & $\begin{array}{c}\% \text { de } \\
\text { proprie- } \\
\text { tários }\end{array}$ & $\begin{array}{c}\% \text { de } \\
\text { escra- } \\
\text { vos }\end{array}$ & $\begin{array}{c}\# \text { de } \\
\text { proprie- } \\
\text { tários }\end{array}$ & $\begin{array}{c}\# \text { de } \\
\text { escra- } \\
\text { vos }\end{array}$ \\
\hline 1 a 9 escravos & 59,7 & 24,1 & 161 & 743 & 62,4 & 20,4 & 402 & 1823 \\
\hline $\begin{array}{l}10 \text { a 19 } \\
\text { escravos }\end{array}$ & 25,9 & 30,5 & 70 & 938 & 19,3 & 18,4 & 124 & 1648 \\
\hline $\begin{array}{l}\text { + de 20 } \\
\text { escravos }\end{array}$ & 14,4 & 45,4 & 39 & 1399 & 18,3 & 61,2 & 118 & 5468 \\
\hline Total & 100 & 100 & 270 & 3080 & 100 & 100 & 644 & 8939 \\
\hline
\end{tabular}

Obs: 34 inventariados não possuíam escravos entre 1789 e 1808, o mesmo ocorrendo com 126 inventariados entre 1810 e 1832.

FONTES: Inventários post-mortem (1789-1832), Arquivo Nacional (Rio de Janeiro); Inventários post-mortem (1825-1832), Primeiro Ofício de Notas de Paraíba do Sul (dados coletados por João Fragoso); Inventários post-mortem (1820-1832), Arquivo Público Judiciário de Itaguaí (dados coletados por Ricardo Muniz de Ruiz).

$\mathrm{O}$ crescimento do tráfico atlântico ulterior à abertura dos portos coloniais ao comércio internacional (1808) exacerbou semelhante perfil e à intensificação dos desembarques de africanos correspondeu uma maior fatia da escravaria possuída pela elite colonial, que passou a deter mais de 
$60 \%$ dos cativos. Paralelamente, diminuiu o acesso à propriedade escrava por parte daqueles que possuíam menos de vinte cativos (de pouco mais da metade passaram a deter cerca de $40 \%$ de escravaria). Ratificando semelhante movimento, o número de proprietários sem escravos aumentou - de 11,2\% dos inventariados entre 1789 e 1808, para 16,4\% entre 1810 e 1830. Em suma, o que se demonstra aqui é o papel estrutural do tráfico atlântico para a afirmação da capacidade dos mais ricos homens livres em gerar renda a partir da apropriação do trabalho escravo. Logo, o comércio negreiro surgia enquanto mecanismo central de afirmação da distância social da elite escravista em relação a outros setores da população livre na hierarquia socioeconômica.

\subsection{VOLUME}

Entre 1790 e 1830, os milhares de africanos desembarcados no porto do Rio de Janeiro supriam por via terrestre à demanda da capitania de Minas Gerais que, com sua economia voltada para o mercado interno, absorvia até $40 \%$ dos escravos vendidos e revendidos por traficantes do Rio de Janeiro. Por via marítima, a capitania do Rio provia também boa parte da demanda por escravos do Rio Grande do Sul, Santa Catarina e São Paulo, e, em menor escala, do Espírito Santo, regiões nas quais os cativos eram empregados na agricultura voltada para os mercados interno e externo, além da pecuária e, mesmo, de setores artesanais e domésticos. Situavam-se no próprio Rio de Janeiro os outros núcleos de demanda por africanos: as fazendas produtoras de cana-de-açúcar (sobretudo da região de Campos dos Goitacás) e aquelas ligadas à produção de alimentos; o centro mercantil formado pela capital e por sua periferia imediata; e a produção cafeeira no Vale do Paraíba, cujas exportações passaram de 160 arrobas, em 1792, para 539 mil em 1820, chegando a $3.237 .190 \mathrm{em} 1835^{9}$.

As flutuações dos desembarques de africanos estão expressas na tabela 2. Dela constam números provenientes de entradas de navios no Rio de Janeiro ocorridas entre 5 de julho de 1795 e o ano de 1830, constantes

9 STEIN, Stanley J. Vassouras: a Brazilian coffee country, 1850-1900. Massachusetts: Harvard University Press, 1957, p. 53. 
do TSTD2 e submetidas aos procedimentos descritos no apêndice 1. A grande lacuna era representada pela ausência de registros de efetivos desembarques entre 1790 e o restante do ano de 1795. Para saná-la, assumi ser plausível que o total de embarques e desembarques observados durante o primeiro semestre de 1795 reproduzisse o mesmo perfil quantitativo e de rotas observado para o segundo semestre do mesmo ano - i.e., que, duplicadas, as cifras resultantes indicassem o total de viagens e de exportados/ importados da região congo-angolana para o porto do Rio de Janeiro. Para o ano de 1790, o TSTD2 não registra entradas reais ou intencionadas no porto do Rio e, para 1791-1794, indica tão somente algumas viagens que, partindo de Luanda, Benguela e "Angola", tencionavam atracar no porto do Rio, sem que, no entanto, haja registro de efetiva atracagem. Diante de tal panorama, preferi trabalhar com as cifras de desembarques de africanos produzidas por Rudolph W. Bauss, que se utilizou dos impostos alfandegários recolhidos sobre os africanos que entraram no porto do Rio de Janeiro entre janeiro de 1790 e dezembro de 1794. De seus números fiz derivar as exportações africanas, mediante a aplicação, para esses anos, do índice médio de mortalidade encontrado no TSTD2 para o período 1796-1800 $(8,3 \%)$. De semelhantes ajustes, e dos números presentes no apêndice 1 , resultou a tabela $2^{10}$.

Grosso modo, pode-se dividir o período 1790-1830 em três intervalos. O primeiro, 1790-1810, de relativa estabilidade, conheceu desembarques médios de 9.967 escravos/ano; o segundo, 1811-1825, acusou a abertura dos portos coloniais ao comércio internacional, do qual resultou a duplicação da média anual de entradas de escravos para 20.908. Por último, o quinquênio 1826-1830, quando o volume do tráfico passou a ser determinado, sobretudo - mas não exclusivamente -, pelo tortuoso processo de reconhecimento da independência brasileira, ocorrida em 1822, pela Grã-Bretanha. Vislumbrando o fim do tráfico, mas, simultaneamente, demonstrando grande capacidade de arregimentação de recursos, as elites escravocratas do sudeste passaram à compra desenfreada de africanos, antes mesmo da ratificação do tratado de 13 de março de 1827, o qual estipulava o fim do tráfico para dali a três anos.

10 Os 715.100 africanos desembarcados no Rio de Janeiro entre 1790 e 130 representam $2.4 \%$ a mais do que os 697.945 que estimei em meu Em costas negras, op. cit. 
TABELA 2 - FLUTUAÇÕES DAS EXPORTAÇÕES/IMPORTAÇÕES DE ESCRAVOS ENTRE A ÁFRICA E O PORTO DO RIO DE JANEIRO, 1790-1830

\begin{tabular}{c|c|c|c|c}
\hline Período & $\begin{array}{c}\text { \# de viagens (entra- } \\
\text { das registradas) }\end{array}$ & $\begin{array}{c}\text { \# de escravos } \\
\text { exportados }\end{array}$ & $\begin{array}{c}\text { \# de escravos } \\
\text { importados }\end{array}$ & $\begin{array}{c}\text { Índices (im- } \\
\text { portação) }\end{array}$ \\
\hline 1790 & - & 6260 & 5740 & \\
\hline $1791-1795$ & - & 52159 & 48021 & 100 \\
\hline $1796-1800$ & 121 & 50583 & 46384 & 96.6 \\
\hline $1801-1805$ & 104 & 54219 & 50667 & 105.5 \\
\hline $1806-1810$ & 134 & 67566 & 58496 & 121.8 \\
\hline $1811-1815$ & 223 & 98973 & 91444 & 190.4 \\
\hline $1816-1820$ & 251 & 111703 & 100447 & 209.2 \\
\hline $1821-1825$ & 288 & 137686 & 121733 & 253.5 \\
\hline $1826-1830$ & 515 & 208435 & 192168 & 400.2 \\
\hline Total & 1660 & 787584 & 715100 & \\
\hline
\end{tabular}

FONTES: Apêndice 1 e BAUSS, Rudolph W. Rio de Janeiro: The rise of late colonial Brazil's dominant imporium, 1777-1808. Tulaine (Lousiania): Dept. of History/Tulaine University, $1977^{11}$.

$\mathrm{Na}$ esteira da corrida por braços, o comércio de homens através do porto do Rio novamente dobrou, com a entrada de 38.434 africanos $/ \mathrm{ano}^{12}$.

Se durante toda a segunda metade do século XVIII desembarcaram no Rio de Janeiro cerca de metade dos africanos aportados no Brasil, de 1810 a 1830 tal proporção variou entre $70 \%$ e $90 \%$ de todas as importações do país ${ }^{13}$. Em uma escala comparativa continental, o total de africanos importados através do Rio de Janeiro entre 1790 e 1810 conformara um volume superior a todo o tráfico ocorrido neste intervalo para os Estados Unidos, América Espanhola e colônias holandesas e dinamarquesas do Caribe juntos. Representava ainda aproximadamente $70 \%$ de todo o trá-

11 Rudolph Bauss trabalhou com o Resumo do Rendimento dos Direitos dos Escravos que Entrarão Neste Porto desde o Primeiro de Janeiro de 1790 athé o fim de dezembro de 1794 (Correspondência do Vice-Rei para a Corte, Códice 68, v. 14, fl. 91, Arquivo Nacional). Encontrou aí impostos anuais de 5:740\$000 réis (1790), 7:478\$000 réis (1791), 8:456\$000 réis (1792), 11:096\$000 réis (1793), 10:225\$000 réis (1794). Observe-se que Bauss assumiu $1 \$ 000$ réis por escravo, o que implica supor terem sido africanos adultos todos os escravos desembarcados no porto do Rio de Janeiro de então.

12 Embora abolido oficialmente em 1830, o tráfico para o Brasil logo foi retomado, em regime de contrabando. Somente em 1850 se dará a abolição definitiva do comércio negreiro brasileiro. ELTIS, David. The nineteenth-century transatlantic slave trade: An annual time series of imports into the Americas broken down by region. Hispanic American Historical Review, v. 67, n. 1, p. 109-38, 1987, passim.

13 Cf. FLORENTINO. Em costas negras, tabela 4. 
fico inglês e $85 \%$ de todo o comércio negreiro francês. Depois de 1810 , quando o tráfico carioca de africanos só encontrava competidores de peso em Cuba, seus desembarques eram de duas a quatro vezes maiores do que os cubanos ${ }^{14}$. Se pensarmos que o tráfico era também um negócio, então o volume das importações cariocas denotará a existência de um portentoso circuito endógeno de acumulação de riquezas, cuja envergadura o singularizava mesmo em relação à agroexportação. Daí ser fundamental descobrir se esta acumulação se direcionava a praças europeias ou se, pelo contrário, assumia um caráter endógeno à formação brasileira.

\subsection{SOBRE ROTAS, COMPRAS E VENDAS}

O século XVIII testemunhou o reiterado predomínio da região congo-angolana como principal fonte de escravos africanos para o Rio de Janeiro, exportados, sobretudo, por meio dos portos de Luanda e de Benguela - ao longo desta centúria, $88 \%$ dos africanos eram originários da África Central Atlântica, contra $11 \%$ de afro-ocidentais e apenas $1 \%$ de afro-orientais ${ }^{15}$. O perfil das entradas de africanos expresso pela tabela 3 reitera parte de semelhante panorama para a última década do século XVIII e as três primeiras do século seguinte. Ao longo desse período, a abertura dos portos coloniais ao comércio internacional converteu-se na variável fundamental para a expansão da economia escravista brasileira, determinando o incremento das exportações na esfera da oferta africana por meio de dois grandes movimentos: no âmbito das macrorregiões, a incorporação mais intensa da África Oriental, e, em cada uma delas, a diversificação das áreas de abastecimento.

Em que pese a proibição do tráfico ao norte do Equador, prevista pelo Congresso de Viena, a participação da África Ocidental no abastecimento do porto do Rio de Janeiro, em queda na passagem do século XVIII para o XIX, não desapareceu por completo, embora depois de 1815 grande

14 CURTIN, Philip D. The Atlantic Slave Trade: a Census. Madison: Wisconsin University Press, 1969, p. 216

15 CAVALCANTI, Nireu Oliveira. O comércio de escravos novos no Rio setecentista. In: FLORENTINO, Manolo (Org.). Tráfico, escravidão e liberdade. Rio de Janeiro: Civilização Brasileira, 2005, passim. 
parte dos afro-ocidentais que chegavam ao Rio de Janeiro proviessem, sobretudo, de outras áreas brasileiras (da Bahia, por exemplo). Parte do tráfico afro-ocidental remanescente tendeu a deslocar-se para a zona setentrional da África Ocidental e a outra para a região do Rio dos Camarões. A viragem do século marcou igualmente o expressivo crescimento relativo e absoluto das exportações da costa índica, com a África Oriental consolidando-se como grande fonte abastecedora de escravos depois de 1811. Em meio a tal processo, deu-se a expressiva diversificação das exportações, antes centradas na ilha de Moçambique, com destaque para a abertura dos portos meridionais de Quilimane, Inhambane, Lourenço Marques e, mesmo, da rota que se iniciava na ilha de Madagascar.

TABELA 3 - PARTICIPAÇÃO (\%) DAS GRANDES ÁREAS DE PROCEDÊNCIA DOS ESCRAVOS AFRICANOS DESEMBARCADOS NO PORTO DO RIO DE JANEIRO, 1795-1830

\begin{tabular}{|c|c|c|c|c|c|}
\hline \multirow[t]{2}{*}{ Macrorregião } & \multirow{2}{*}{$\begin{array}{l}\text { Porto/Região de } \\
\text { embarque }\end{array}$} & \multicolumn{2}{|c|}{$1795-1810$} & \multicolumn{2}{|c|}{$1811-1830$} \\
\hline & & $\begin{array}{l}\% \text { de im- } \\
\text { portados na } \\
\text { macrorre- } \\
\text { gião }\end{array}$ & $\begin{array}{c}\% \text { de } \\
\text { importa- } \\
\text { dos da ma- } \\
\text { crorregião }\end{array}$ & $\begin{array}{c}\% \text { de } \\
\text { importa- } \\
\text { dos na ma- } \\
\text { crorregião }\end{array}$ & $\begin{array}{c}\% \text { de } \\
\text { importa- } \\
\text { dos da } \\
\text { ma-crorre- } \\
\text { gião }\end{array}$ \\
\hline \multirow{13}{*}{$\begin{array}{l}\text { África } \\
\text { Ocidental }\end{array}$} & & 100 & 1,3 & 100 & 1,5 \\
\hline & Anomabu (Serra & - & & 9,9 & \\
\hline & Leoa) & & & & \\
\hline & Ajuda & - & & 6,6 & \\
\hline & Lagos & - & & 5,0 & \\
\hline & "Costa do Ouro" & - & & 10,1 & \\
\hline & "Costa da Mina" & 18,2 & & 4,5 & \\
\hline & Bonny & 11,9 & & 4,1 & \\
\hline & Velho Calabar & 32,9 & & 11,1 & \\
\hline & Rio Camerum & - & & 31,6 & \\
\hline & Gabão & 10,9 & & 1,4 & \\
\hline & Ilha de São Tomé & 26,1 & & 13,6 & \\
\hline & Ilha do Príncipe & - & & 2,1 & \\
\hline
\end{tabular}


Tabela 3 (continuação).

\begin{tabular}{|c|c|c|c|c|c|}
\hline \multirow[t]{2}{*}{ Macrorregião } & \multirow{2}{*}{$\begin{array}{l}\text { Porto/Região de } \\
\text { embarque }\end{array}$} & \multicolumn{2}{|c|}{$1795-1810$} & \multicolumn{2}{|c|}{$1811-1830$} \\
\hline & & $\begin{array}{l}\% \text { de im- } \\
\text { portados na } \\
\text { macrorre- } \\
\text { gião }\end{array}$ & $\begin{array}{c}\% \text { de } \\
\text { importa- } \\
\text { dos da ma- } \\
\text { crorregião }\end{array}$ & $\begin{array}{c}\% \text { de } \\
\text { importa- } \\
\text { dos na ma- } \\
\text { crorregião }\end{array}$ & $\begin{array}{c}\% \text { de } \\
\text { importa- } \\
\text { dos da ma- } \\
\text { crorregião }\end{array}$ \\
\hline \multirow{10}{*}{$\begin{array}{l}\text { África Central } \\
\text { Atlântica }\end{array}$} & & 100 & 96,6 & 100 & 76,7 \\
\hline & Loango & - & & 0,2 & \\
\hline & Molembo & 0,3 & & 1,4 & \\
\hline & Cabinda & 3,2 & & 34,2 & \\
\hline & "Norte do Congo" & - & & 0,1 & \\
\hline & Congo & - & & 3,3 & \\
\hline & Ambriz & - & & 8,3 & \\
\hline & Luanda & 26,1 & & 8,8 & \\
\hline & Benguela & 48,1 & & 18,1 & \\
\hline & "Angola" & 22,3 & & 25,6 & \\
\hline \multirow[t]{6}{*}{ África Oriental } & & 100 & 2,1 & 100 & 21,8 \\
\hline & "Moçambique" & 100 & & 51,6 & \\
\hline & Quilimane & - & & 35,9 & \\
\hline & Inhambane & - & & 3,4 & \\
\hline & Lourenço Marques & - & & 3,4 & \\
\hline & Madagascar & - & & 5,7 & \\
\hline Total & & & 100 & & 100 \\
\hline
\end{tabular}

FONTE: Apêndice 1.

É possível que o crescimento das exportações afro-orientais denotasse a relativa incapacidade da zona congo-angolana em responder de imediato à súbita alta da demanda do sudeste brasileiro após 1808. Apesar disso, a África Central Atlântica continuou a deter o virtual monopólio do abastecimento de escravos para o porto do Rio de Janeiro. Semelhante perfil é reafirmado pelo fato de que, durante as três primeiras décadas do Oitocentos, as listagens de escravos em inventários post-mortem indiquem que oito entre cada dez africanos que viviam na capitania do Rio de Janei- 
ro eram bantos congo-angolanos. Contudo, a partir de 1810 importantes modificações ocorreram, com ênfase especial para a incorporação mais intensa da porção setentrional da África Central Atlântica. Incrementava-se a hegemonia dos luso-brasileiros no comércio negreiro ao norte de Luanda, após a progressiva retirada de traficantes holandeses, ingleses e franceses, inicialmente em função das guerras napoleônicas na Europa, e, depois, porque importantes metrópoles proibiram o tráfico de escravos. Com isso, ganharam terreno os interesses dos traficantes luso-brasileiros em Estados como Angoi, Congo, Cacongo e Loango, e o porto de Cabinda transformouse em grande centro exportador de africanos ${ }^{16}$.

É necessário refletir teoricamente sobre a oferta africana de milhões de pessoas sem que, no fundamental, os traficantes europeus e americanos os apresassem diretamente. Fixemos a atenção no tráfico originário da zona congo-angolana.

Os cenários privilegiados eram os portos do Atlântico, palcos de um duplo fluxo: o da exportação de cativos, trazidos do interior para a costa, e o da importação de bens europeus e americanos, logo despachados do litoral para as savanas e áreas florestais. Fluxos complementares e, por isso mesmo, inseparáveis do ponto de vista analítico, seu bom funcionamento dependia da existência, na África, de três tipos de agentes socioeconômicos: os mercadores nativos sediados nos portos, detentores dos bens importados para a realização do escambo, recebidos adiantadamente dos capitães dos navios negreiros; os régulos interioranos, que proviam os primeiros com os escravos apresados; e os pequenos comerciantes nativos, que faziam a intermediação entre os dois primeiros agentes ${ }^{17}$. Após semanas ou meses deslocando-se pelas savanas e florestas, as centenas de pequenos traficantes nativos - pumbeiros, aviados, funantes ou sertanejos - e seus carregadores contatavam as autoridades interioranas que detinham o monopólio do apresamento de escravos. Estas em geral não estocavam prisioneiros, evitando gastos com a sua manutenção. Ao invés, esperava-se pela chegada dos sertanejos para, depois de acertados os termos da troca e recebidas

16 Cf. também CURTO, José C.; GERVAIS, Raymond R. A dinâmica demográfica de Luanda no contexto do tráfico de escravos do Atlântico Sul, 1781-1844. Topoi, v. 4, p. 85-138, mar. 2002.

17 Baseado em MILLER, Joseph C. Way of Death. Madison: Wisconsin University Press, 1987. 
adiantadamente as mercadorias do escambo, produzir prisioneiros nas áreas fronteiriças. Transferidos aos sertanejos, os grupos de cativos (libambos ou quibucas) eram reunidos até que se atingisse o número requerido pelos mercadores dos portos angolanos ${ }^{18}$.

Três entre cada quatro escravos transportados do interior para o litoral africano eram prisioneiros de guerra ${ }^{19}$. As guerras viabilizavam a produção maciça e contínua de homens na África mais afetada pelo tráfico. Tal movimento criava ou simplesmente acentuava relações desiguais de poder entre os africanos, implicando no fortalecimento do Estado - única instituição capaz de produzir cativos em grande escala. Daí não causar surpresa que, durante o auge do tráfico no século XVIII, a maior parte das sociedades africanas sem Estado estivesse fora dos principais eixos do comércio negreiro. Está-se, pois, diante da primeira face de um movimento sociológico profundo: à aquisição de bens no litoral e sua troca por prisioneiros no interior correspondia o fortalecimento político e econômico dos grupos dominantes nativos. Através da guerra, em especial daquelas que envolviam Estados, acentuava-se a diferenciação social entre as classes e frações de classes, entre as etnias, e, no interior das aldeias, entre os mais velhos e os mais novos. A guerra fundadora da condição escrava estava, em suma, na origem tanto do movimento que viabilizava o atendimento da demanda americana por braços quanto no cerne da diferenciação social e da expansão do fenômeno estatal na África. O tráfico apresentava ainda uma segunda dimensão, de certo modo ligada à primeira. Embora a maior parte dos capturados se destinasse à troca por mercadorias europeias e americanas, era cada vez maior a utilização dos escravos produzidos através da guerra dentro do próprio continente africano. Não é fortuito que os estudiosos indiquem grande incidência de escravos entre as populações das maiores sociedades estatais africanas ${ }^{20}$. Era a violência que, ao transformar o homem em escravo, permitia às elites das sociedades captoras acumularem a riqueza maior - os homens ${ }^{21}$.

18 Cf. SILVA, Alberto da Costa e. A manilha e o libambo: a África e a escravidão, de 1550 a 1700. Rio de Janeiro: Nova Fronteira, 2002, para os séculos XVI e XVII.

19 FAGE, J. D. History of West Africa. London: Cambridge University Press, 1959, p. 94.

20 Cf. GRAY, Richard. Introduction. In: The Cambridge History of Africa, v. 4, p. 1-13, 1977; e MANNING, Patrick. Slavery and African life. Cambridge: Cambridge University Press, 1990.

21 THORNTON, John. Africa and Africans in the making of the Atlantic world, 1450-1680. New York: Cambridge University Press, 1992. 
A violência fundadora da condição de escravo dissociava o valor mercantil do custo social de produção do cativo ${ }^{22}$. Daí que a troca inicial de bens por homens, no interior africano, implicasse na apropriação, por parte de mercadores e das elites nativas, de grande parcela do trabalho despendido pelas comunidades locais. Todas as etapas seguintes da circulação do cativo girariam ao redor da repartição do trabalho expropriado. Como em uma correia de transmissão, a não equivalência se transportava para as fases seguintes de circulação da mercadoria viva até a América portuguesa, quando os preços que os cativos alcançavam em sucessivas compras e vendas não expressavam seu valor social, o que permitia mesmo a homens livres de minguadas posses adquirirem ao menos um escravo.

Na Luanda do século XVIII comprava-se um homem adulto em boas condições físicas por quinze chapéus finos, ou em troca de quatorze pares de meias de seda. Três barris de pólvora ou 23 volumes de livros em branco também facultavam a aquisição de um escravo, e com um cavalo ou dois barris de cachaça adquiriam-se dois mais. De cada $1 \$ 000$ réis da pauta de importações angolana, $\$ 600$ destinavam-se à compra de têxteis, objetos de adorno e vestuário, $\$ 200$ à de bebidas e $\$ 110$ à aquisição de mantimentos e armas. Com o resto obtinham-se diversos gêneros menores, como materiais de construção, especiarias, cauris e tabaco ${ }^{23}$. A julgar pelo Autor Anônimo que escreveu sobre o tráfico em meados do século XVIII, tal padrão remontava à própria instauração do tráfico em Angola, pois "desde o princípio" o escambo tinha por base "víveres, licores e fazendas"24.

Do Estado da Índia vinha em torno de 1/3 de tudo que Angola importava - o resto provinha em partes mais ou menos iguais do Brasil, de Portugal e, por intermédio desse, dos países da Europa do Norte. Portugal vendia a Angola, sobretudo, panos, bebidas e mantimentos - cf. gráfico 1.

22 MEILlASSOUX, Claude. L'anthropologie de l'esclavage. Paris, PUF, 1985, passim.

23 Cf. Balanço da importação e exportação deste Reino de Angola desde o anno de 1785 em que teve principio o estabelecimento da alfândega até o anno de 1794 inclusive. Arquivo do Instituto Histórico e Geográfico Brasileiro (RJ), Seção dos Manuscritos, lata 77, documento 1. Por certo, muitos produtos destinavam-se a atender a outras demandas que não o tráfico, mas somavam valores ínfimos se comparados àqueles alocados à aquisição de cativos. Daí ser possível que as compras registradas na Alfândega luandense reflitam, sobretudo, os bens formadores do estoque do escambo. Sobre o papel destes bens na economia tradicional africana, ver MILLER, op. cit., passim.

24 AUTOR ANÔNIMO. Instruções em que se mostra a formalidade do comércio do Reyno de Angola e Benguella, e o quanto tinha florescido desde o seu princípio athé o anno de 1760 em que principiou a sua ruina... (Seção de Manuscritos da Biblioteca Nacional, v. I, p. 4455-94). 
Os têxteis representavam $75 \%$ das vendas de outros países europeus, e perto de $60 \%$ das vendas brasileiras para Angola compunha-se de aguardente de cana e uma fração menor, (15\%), de mantimentos. Entretanto, a moeda por excelência para a compra de escravos eram os panos da Índia $(99 \%$ das vendas orientais para Angola) - cf. gráfico 2.

\section{GRÁFICO 1 - PARTICIPAÇÃO (POR \% DOS VALORES) DAS ÁREAS DE ORIGEM DOS BENS IMPORTADOS PELO PORTO DE LUANDA, 1785-1794}

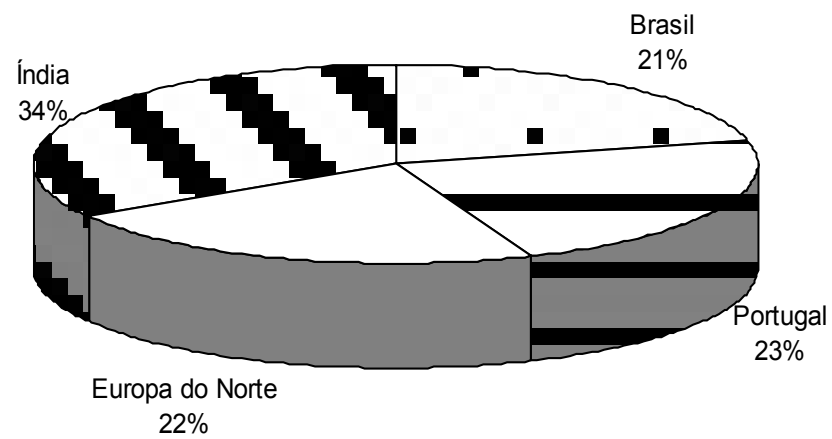

FONTE: Balanço da importação e exportação deste Reino de Angola desde o anno de 1785 em que teve princípio o estabelecimento da alfândega até o anno de 1794 inclusive. Arquivo do Instituto Histórico e Geográfico Brasileiro (RJ), Seção dos Manuscritos, lata 77, documento 1.

Em fins do século XVIII, 1/3 dos tecidos de algodão remetidos ao Brasil pela Metrópole eram panos brancos asiáticos que apenas recebiam as estampas em Portuga ${ }^{25}$. Supondo que o mesmo ocorresse com a terça parte dos tecidos vendidos por Lisboa à África, então os panos asiáticos representariam mais de $60 \%$ dos têxteis trocados por cativos. Isto daria à Índia uma participação efetiva (direta e indireta) de 40\% nas compras efetuadas por Luanda. Por conseguinte, juntos, os produtos do Estado da

25 "As remessas de tecidos de algodão ascenderam a números muito avultados que fizeram deles a mais valiosa exportação portuguesa para o Brasil em finais do século XVIII e começos do XIX" (ALEXANDRE, Valentim. Os sentidos do Império. Lisboa: Afrontamento, 1993, p. 49). Na página seguinte, Valentim Alexandre informa que "uma parte infelizmente não quantificável destes tecidos correspondia a panos brancos provenientes da Ásia que, uma vez estampados em Portugal, eram remetidos para o Brasil". Ver também PEDREIRA, Jorge. Homens de negócio da Praça de Lisboa. Lisboa: Universidade Nova de Lisboa, 1996, capítulos 1 e 2 (Tese de doutoramento). 
Índia e das feitorias da América portuguesa contribuiriam com mais de 60\% dos valores formadores do escambo angolano durante a segunda metade do século XVIII - mais um dado a questionar frontalmente os teóricos da dependência.

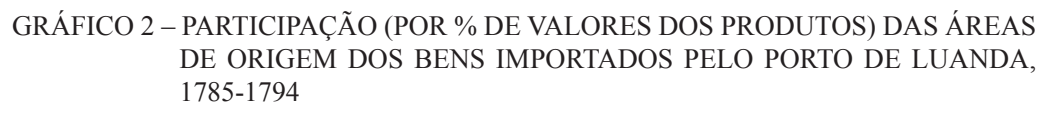
DE ORIGEM DOS BENS IMPORTADOS PELO PORTO DE LUANDA, 1785-1794

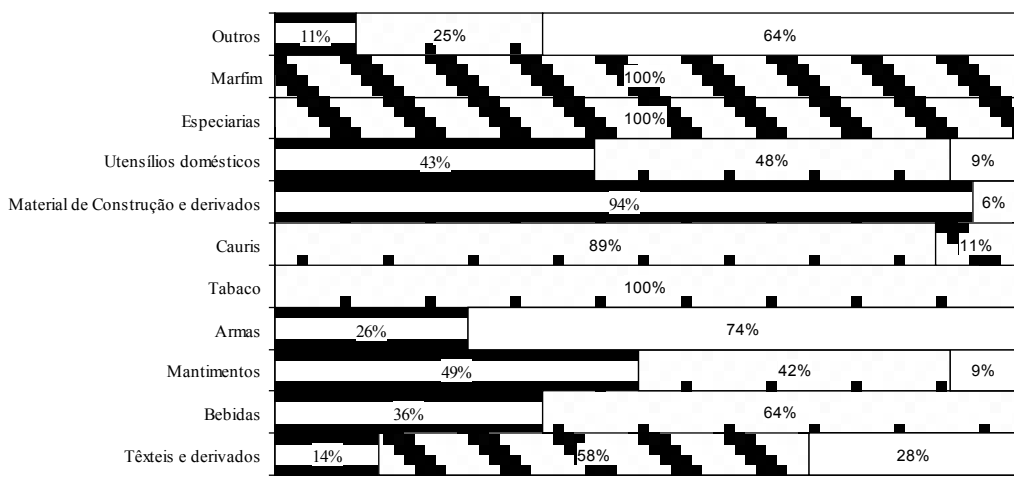

$\square$ Portugal $\square$ Brasil $\square$ Ásia $\square$ Europa do Norte

FONTE: A mesma do gráfico 1.

Com o Oitocentos, as fontes das importações angolanas se modificaram. Durante os dois primeiros anos da estadia dos Bragança no Brasil, a América portuguesa contribuiu com $1 / 3$ das compras africanas, a mesma cifra observada para as importações provenientes da Europa e da Ásia. Entre 1810 e 1812, entretanto, a participação do Rio de Janeiro disparou - para 2/3 em 1810 e $75 \%$ nos dois anos seguintes ${ }^{26}$. Corresponderia a este movimento uma maior participação da produção brasileira no conjunto das compras luandenses? Aparentemente não. É certo que somente a aguardente de cana representava 1/4 das compras angolanas em 1808-1809. Mas se, por então, as fazendas compunham $2 / 3$ dos bens do escambo, nos três anos seguintes, quando Angola adquiria no Brasil a maior parte de suas importações, os

26 Resumo dos Mappas de Importação e Exportação... 1808-1814. Arquivo Nacional, Junta do Comércio, caixa 448, pacote 1 . 
panos representavam pouco mais de $70 \%$ das compras africanas ${ }^{27}$. É fácil deduzir que, com a abertura dos portos e a respectiva centralização dos fluxos de aquisições africanas no porto carioca, incrementou-se a participação dos têxteis entre os produtos trocados por escravos em uma proporção maior do que aquela observada em fins do século XVIII, com a respectiva diminuição relativa de bebidas, mantimentos e armas.

Se às importações angolanas efetuadas diretamente na Ásia somarmos os panos indianos que, através do Rio de Janeiro, chegavam a Luanda, e aqueles que também via Rio atingiam o mercado africano depois de receberem estampas em Portugal, teremos que a Índia continuava a deter nas compras angolanas do início da década de 1810 a mesma participação verificada em fins do Setecentos. A novidade do século que se iniciava era o aumento da participação dos manufaturados europeus no escambo, em especial dos bens originários dos países do norte da Europa. Não é difícil imaginar a raiz desta mutação, já que a produção manufatureira europeia podia atender com maior presteza às demandas derivadas do súbito crescimento das exportações africanas. Talvez se possa postular que nas primeiras décadas do século XIX a esfera sul-sul do império português (Brasil e Estado da Índia) contribuísse com metade dos valores que formavam os bens do escambo congo-angolano, cabendo à Metrópole e, sobretudo, a outros países da Europa, os outros 50\%.

\subsection{ASPECTOS DA EMPRESA TRAFICANTE}

Desde o século XVIII, o tráfico para o porto carioca era financiado pelos traficantes do Rio de Janeiro ${ }^{28}$. Os inventários post-mortem desses comerciantes não apresentam déficits para com casas mercantis europeias ou da Índia, o que significa dizer estarem eles longe da condição de meros representantes de casas comerciais estrangeiras ${ }^{29}$. Na verdade, proprietários

27 Idem. Os mesmos documentos indicam que em 1813, em tecidos, o Rio exportou para Angola 428:623\$932 réis de um total de 600:218\$602 réis.

28 Cf. RODRIGUES, José H. Brasil e África: outro horizonte. Rio de Janeiro: Civilização Brasileira, 1964, p. 27-30. Glasgow afirma que desde a segunda metade do século XVII o tráfico angolano era controlado por comerciantes brasileiros (op. cit., p. 146-147) - GLASGOW, Roy. Nzinga. São Paulo: Perspectiva, 1982.

29 FLORENTINO, op. cit., passim. 
que eram de $3 / 4$ dos negreiros que transportavam os escravos e as mercadorias formadoras do escambo, os traficantes do Rio de Janeiro se utilizavam de três mecanismos para adquirir os bens europeus e orientais que, junto com os produtos coloniais, viabilizavam as compras de escravos na África. Muitos compravam os bens na própria África, junto a importadores europeus e luso-africanos, o que redundava em expressivas remessas de dinheiro para Angola, tanto sob a forma de letras de câmbio como de ouro amoedado. Outros adquiriam os manufaturados na Europa e na Índia, de onde os exportavam diretamente para a África, também implicando em remessa para a Europa e para a Ásia de letras e, sobretudo, de moeda sonante. Embora continuassem a viger após 1808, é possível que estes mecanismos - particularmente o primeiro - tenham dominado a formação do escambo antes da abertura dos portos brasileiros. Havia, por fim, o sistema predominante depois de 1808, calcado na importação dos produtos da Europa e da Índia, e sua posterior reexportação para a África.

Por exemplo, a sociedade mercantil estabelecida entre o capitão Manoel Gonçalves Moledo, do Rio de Janeiro, e Ignácio Correia Picanço, de Benguela, constituía seus estoques para o escambo combinando o envio de manufaturados de Portugal diretamente para a África e a aquisição de mercadorias estrangeiras em Angola. Das remessas realizadas pelo sócio do Rio, em 1804, 90\% eram constituídas por dinheiro e $10 \%$ por aguardente. No ano seguinte, as fazendas, aparentemente remetidas de Portugal para Benguela, representavam 1/3 dos gastos do sócio brasileiro, com moedas e letras representando pelo menos 50\%. Somente em 1808 é que os tecidos comprados em Lisboa - e de lá enviados diretamente a Benguela - superaram os envios de dinheiro ${ }^{30}$. Caso ilustrativo da forma prevalecente de formação do escambo depois da chegada dos Bragança ao Brasil nos é oferecido pela correspondência do traficante Manoel Gonçalves de Carvalho com seu representante em Angola, Antônio Alves da Silva. Enviaram-se a este, em outubro de 1819, 30 fardos de fazendas e 20 barris de bebidas "muito bons gêneros para o país [...] onde a qualidade é escassa". segundo Carvalho. Exigia-se por eles "escravos novos que sejam bons ainda que custem alguma meio dobra".

30 Processo de seqüestro de Bens de Micaela Joaquina Nobre contra o Testamenteiro dos Bens de João Luciano Moura, Antônio Lopes Anjo (Junta do Comércio, Arquivo Nacional, 1809, caixa 361, pacote 3). 
Os tecidos, observe-se, haviam sido comprados em Malabar e chegaram a Angola via Rio de Janeiro ${ }^{31}$.

Sobre outro grande traficante, Elias Antônio Lopes, sabe-se que, em 1812 e 1814, carregados de fazendas importadas, dois de seus navios compravam escravos em Cabinda. Quando de sua morte, em 1814, os armazéns da Alfândega do Rio estavam abarrotados de inúmeros tipos de têxteis de sua propriedade, os quais, provenientes de Goa, valiam 46:653\$806 réis - nada menos do que $1 / 5$ de sua enorme fortuna. Elias morreu dominando uma enorme rede mercantil, através da qual adquiria mercadorias para o escambo (mas não somente) em centros mercantis transcontinentais como Lisboa, Porto, Londres, Hamburgo, Amsterdã e Goa, e escravos em Luanda, Benguela e Moçambique.

O caso de Elias Antônio Lopes demonstra que, antes mesmo da vinda da corte lisboeta para o Brasil, os traficantes cariocas já utilizavam o porto do Rio como ponto de reexportação de bens para o escambo. Assim, em 1803, a galera Resolução viera da cidade do Porto para o Rio carregada por sua conta e de seus sócios, partindo logo depois para o resgate de escravos em Angola ${ }^{32}$. Há, inclusive, registros atestando que, em meados do século XVIII, do Rio de Janeiro se enviava para Angola e Benguela os gêneros da Europa, da Ásia, dinheiro em meias dobles, aguardentes e outros gêneros ${ }^{33}$.

Antes de 1808, porém, repitamos, é plausível que a maior parte das mercadorias não brasileiras que compunham os bens de escambo comprados pelos mercadores da praça carioca fosse diretamente de Lisboa ou Goa para Angola, sem escalas no Brasil ${ }^{34}$. É o que mostra o processo aberto na Junta do Comércio pelo traficante Bernardo Lourenço Vianna, do Rio de Janeiro, contra seu devedor, Antônio Rodrigues de Moura, comerciante de grosso trato estabelecido em Luanda. As relações entre os dois litigantes remontavam a pelo menos 1800, quando Antônio de Souza Portella, negociante de Lisboa, em nome de Vianna, emprestou vultosos recursos a Moura. Durante

31 Cf. Junta do Comércio, Arquivo Nacional, caixa 398, pacote 1.

32 Cf. parte de seu inventário na Junta do Comércio, cx. 348, pacote 1, Arquivo Nacional (RJ).

33 Descrição do Estado do Brasil, suas Capitanias, produções e comércio, documento pertencente ao acervo do Museu Britânico (códice 13981), citado por RODRIGUES, op. cit., 1964, p. 26.

34 Corcino Medeiros dos Santos também indica ter sido fundamental o comércio Índia-Angola. Assim, entre 1785 e 1794, a documentação da Alfândega de Luanda indica ser a Índia o principal parceiro dos luandenses (de onde se importavam, sobretudo, têxteis) - cf. seu livro O Rio de Janeiro e a conjuntura atlântica. São Paulo: Expressão e Cultura, 1993, p. 156. 
os quatro primeiros anos o negociante angolano quitou parcelas da dívida, mas, depois de 1804, os pagamentos simplesmente cessaram. Desde então, Portella falecera, sua casa de comércio faliu e as dívidas do comerciante angolano para com o traficante carioca se acumularam, chegando a mais de vinte mil cruzados (8:000\$000 réis). O financiamento de Vianna destinava-se à compra de mercadorias na Ásia, sendo o comerciante lisboeta, Portella, um mero intermediário ${ }^{35}$.

Todo o processo mercantil girava ao redor da figura do adiantamento das mercadorias: os comerciantes angolanos adiantavam fazendas, aguardente, tabaco, armas e pólvora aos sertanejos, que com elas se dirigiam ao interior para a troca por escravos. Antes, porém, em consignação, eles recebiam as mercadorias dos capitães dos negreiros, endividando-se frente ao capital traficante do Rio de Janeiro. A partir daí, suas dívidas para com as autoridades da Coroa, para com os arrematadores de contrato de escravos ou para com os fornecedores privados eram pagas em letras passadas e quitadas pelos negociantes do Rio de Janeiro. Por isso é que, segundo o Autor Anônimo, durante a segunda metade do século XVIII as letras cariocas chegaram a circular como numerário em Benguela ${ }^{36 !}$

Obter altos lucros era a ilusão que movia os traficantes. Já na África, porém, a empreitada negreira perdia muitos escravos. A Memória a respeito dos escravos e tráfico da escravatura entre a costa d'África e o Brazil, apresentada por Oliveira Mendes à Real Academia de Ciências de Lisboa, em 1793, estimava que por então perdia-se de $30 \%$ a $50 \%$ dos escravos no longo trajeto entre as zonas de captura no interior de Angola e o porto de Luanda ${ }^{37}$. No outro extremo do continente, de acordo com dados elaborados pelo Frei Bartolomeu dos Mártires para o ano de 1819, quase $20 \%$ dos escravos que partiam de Moçambique para o Rio de Janeiro, Bahia e Pernambuco pereciam entre a sua compra e o seu embarque em portos moçambicanos - cálculo referente basicamente ao tempo de espera para o preenchimento para a lotação de cada navio ${ }^{38}$. Em Angola, um ou

35 Junta do Comércio, Arquivo Nacional, caixa 377, pacote 1.

36 AUTOR ANÔNIMO. Op. cit.

37 MENDES, Luiz Antonio de Oliveira. Memória a respeito dos escravos e tráfico da escravatura entre a costa d'África e o Brazil apresentada à Real Academia de Ciências de Lisboa em 1793. Porto, Escorpião, 1977, p. 48.

38 Cf. CAPELA. O tráfico de escravos nos portos de Moçambique, 1733-1904, p. 260-261. 
dois entre cada dez que conseguiam chegar ao litoral pereciam em fétidos armazéns portuários, na longa espera do embarque, e um entre cada vinte sobreviventes fugia dos armazéns ou, muito doente, era simplesmente abandonado no porto de embarque ${ }^{39}$.

Nada, no entanto, igualava-se à arriscada travessia oceânica, e no mar frequentemente se perdiam escravos para corsários ou em naufrágios. Mas as mortes dentro dos negreiros por falta de alimentos e água, por maus tratos, superlotação e medo - o pavor que debilitava o corpo e a alma dos homens - representavam o principal fator de perda para os traficantes. Alguns poucos negreiros praticamente não perdiam escravos, enquanto em outros as mortandades levavam metade da mercadoria vivas, havendo casos de naus que chegavam ao Brasil sem um único escravo vivo. No fundamental, o número de mortos dependia da duração da travessia oceânica, ou seja, da distância entre as regiões africanas de embarque e os portos de recepção no Brasil.

$\mathrm{O}$ apêndice 1 permite comparar as taxas de mortalidade em naus provenientes das macrorregiões africanas que abasteciam o porto do Rio de Janeiro entre 1796 e 1830 . Ele mostra que, em geral, perdia-se de duas a três vezes mais escravos entre os embarcados no Índico do que entre os exportados através da zona congo-angolana. Obviamente, esta diferença se explica pela duração da travessia: enquanto os negreiros provenientes desta última região navegavam de 33 a 43 dias até o Rio de Janeiro, os daquela podiam navegar durante até 76 dias. Com o passar do tempo, reduziram-se os níveis de mortalidade a bordo em ambas as áreas, e o motivo é simples: entre fins do século XVIII e a década de 1820, a duração média da viagem diminuiu em $15 \%$ para os negreiros que zarpavam da África Central Atlântica e em 20\% para aqueles que vinham de Moçambique. É possível que a abreviação do tempo de viagem - e, portanto, da mortalidade - estivesse relacionada ao crescimento da participação de pequenas naus, em princípio mais velozes, pertencentes a traficantes não especializados. É também certo que se morria mais nos séculos XVI e XVII, quando os barcos eram mais toscos e menos velozes do que os construídos a partir de meados do século

39 MILLER, Joseph C. Mortality in the Atlantic slave trade: statistical evidence on causality. Journal of Interdisciplinary History, v. 3, p. 385-523, 1981, p. 413-414; cf. também CARREIRA, Antônio. A Companhia Geral do Grão-Pará e Maranhão. São Paulo: Cia. Editora Nacional/Instituto Nacional do Livro, 1988, p. 136. 
$\mathrm{XVIII}^{40}$. Óbvio, o risco não cessava com o desembarque no Brasil, onde muitos escravos chegavam doentes e pereciam antes mesmo da revenda. $\mathrm{O}$ enfrentamento a um novo ambiente pleno de enfermidades desconhecidas, a espera até a conclusão das vendas e o longo trajeto até o interior brasileiro - todas estas novas experiências poderiam ser fatais. Não chega a surpreender que $25 \%$ dos africanos que acabavam de chegar morressem antes de alcançar seu destino definitivo ${ }^{41}$.

Apenas 5\% das 279 empresas de traficantes que viabilizaram o tráfico entre a África e o porto do Rio de Janeiro entre 1811 e 1830 atuaram durante todo o período, financiando uma ou mais viagens por ano. Elas foram responsáveis por $43 \%$ do total de expedições, constituindo o grupo monopolista de traficantes especializados. Outras empresas $-9 \%$ do total - montaram somente uma expedição negreira a cada dois ou três anos e foram responsáveis por aproximadamente $1 / 5$ do total das expedições. Havia por último aquele grupo de empresários de eventual passagem pelo circuito atlântico de homens ( $86 \%$ do total de empresas), os quais em média puderam organizar apenas uma expedição negreira a cada quatro ou mais anos, e que no final foram responsáveis por 1/3 das viagens à África. Eram os aventureiros que sem serem especializados tinham no tráfico uma atividade meramente especulativa.

Estes números são suficientes para exemplificar como o comércio de homens era concentrado. É óbvio que a compra ou aluguel dos navios, sua equipagem com pessoal - mestres, contramestres, cirurgiões, capelães e marinheiros, estes últimos quase sempre escravos - e ferramentas especializadas, com alimento e, o mais importante, com produtos para o escambo, tudo isto tornava as viagens extremamente caras. Se lembrarmos o quanto era arriscado comprar e vender homens, será fácil entendermos por que tão poucos empresários possuíam capitais suficientes para serem verdadeiros traficantes. $\mathrm{O}$ fato de atuarem continuamente, organizando em média uma

40 De acordo com Glasgow, no século XVII a mortalidade na rota Angola-Brasil era de mais ou menos $30 \%$ (cf. op. cit., p. 140).

41 MELLO, Pedro Carvalho de. Estimativa da longevidade de escravos no Brasil na segunda metade do século XIX. Estudos Econômicos, v. 13, n. 1, p. 172-3, 1983, passim. 
ou mais expedições a cada ano, revela ainda uma grande especialização profissional.

Embora custoso e seletivo, o tráfico era um negócio em que a figura do especulador assumia um papel central. Assim, embora quase $90 \%$ dos traficantes cariocas não participassem continuamente da aventura negreira, eles eram responsáveis por cerca de $1 / 3$ das viagens realizadas à África, cifra que indica o quanto estes aventureiros eram importantes para o adequado atendimento da demanda brasileira. Tais especuladores ou traficantes eventuais eram, na verdade, comerciantes urbanos que em determinados momentos buscavam enriquecer ainda mais por meio da venda de escravos. Eram também antigos comandantes de negreiros que, depois de muito viajarem e desempenharem na África o papel de principais elos de ligação com os comerciantes nativos, adquiriam o conhecimento, a experiência e os recursos necessários para montarem expedições independentes, passando eles próprios a atuar como traficantes. Tal como no caso dos piratas e, mais do que qualquer outro tipo de traficante, a ação destes aventureiros aumentava em momentos de maior demanda por escravos e, portanto, de maior cotação dos mesmos no mercado.

Quanto se lucrava comerciando homens? Que estratégias eram postas em prática?

Do ponto de vista dos comerciantes de almas, o negócio negreiro se iniciava com o dinheiro (moedas, créditos ou letras) investido na aquisição das mercadorias para o escambo, na compra ou aluguel do navio, na manutenção da tripulação e da escravaria e no seguro de todo o empreendimento. Todos estes bens logo se convertiam em mercadorias humanas junto a comerciantes e autoridades africanos. Efetuada a troca na África, o cativo era embarcado para o Brasil, levado ao mercado e, com a venda, novamente assumia a forma de moedas, crédito ou letras - o lucro bruto do traficante. Os recursos monetários auferidos deveriam ser suficientes para pagar todas as despesas, com o restante convertendo-se no lucro líquido.

Ao fim deste ciclo, a envergadura da lucratividade dos negócios negreiros dependia aparentemente apenas da diferença entre o preço de compra e de venda das mercadorias em jogo. Para tanto, o traficante brasileiro desfrutava de uma substancial vantagem: o valor mínimo pelo qual ele podia vender o escravo era relativamente baixo. Produto da violência pura e simples, configurada na captura do escravo, já se viu que este possuía um 
baixíssimo valor inicial medido em horas-trabalho. Por isto é que, mesmo vendendo-o, por um preço socialmente baixo, ainda assim o mercador de almas podia obter expressivas vantagens. A atividade traficante quase sempre redundava, pois, em ganhos reais. Em um plano mais geral, contudo, o traficante era um comerciante como outro qualquer. Daí que o motivasse não a simples obtenção de lucros "razoáveis", mas sim as mais altas taxas de lucratividade possíveis. Como consegui-las?

Para compreender suas opções, partamos da ideia de que no Brasil mesmo os mais pobres proprietários podiam possuir um cativo. Isso sugere que o preço do escravo não atingiu níveis exorbitantes, indicando que a lucratividade dos negreiros não se baseava tão somente no aumento dos preços de venda do africano no Brasil. De fato, para o traficante era mais fácil fazer com que os agentes africanos cobrassem o mínimo possível por sua mercadoria. Afinal, não eram eles seus devedores desde que aceitaram o adiantamento dos bens necessários ao escambo? Este simples movimento já permitiria ao comerciante de almas conseguir altas taxas de lucratividade. Mas, repita-se, a ele interessavam os maiores lucros possíveis, pelo que realizava um segundo movimento: ganhar mais por meio da importação do maior número possível de escravos. Em suma, o traficante aumentava sua rentabilidade pressionando para baixo os preços da oferta e, ao mesmo tempo, multiplicando o diferencial entre o preço de compra e o de venda através do aumento da quantidade de escravos adquiridos.

Na posição de credor dos intermediários mercantis africanos, o traficante carioca, sobretudo aquele de atuação mais frequente, tinha força suficiente para impedir altas muito pronunciadas da mercadoria que lhe era oferecida. Assim, a estratégia inicial do empresário escravista se pautava na busca do controle dos preços ou, pelo menos, a inibição na esfera da oferta. Uma vez bem-sucedidos nesta estratégia, a lucratividade da empreitada negreira passava a repousar mais na multiplicação do número de escravos a serem adquiridos e menos na dilatação entre os preços de compra e venda dos mesmos. Por isto é que a chave para entender a formação do lucro do tráfico era o montante do investimento inicial para a formação dos bens do escambo - ou seja, para a aquisição daquelas mercadorias cujos valores definiriam a quantidade de escravos a serem comprados. traficante?

Não haveria, porém, mecanismos outros que aumentassem o lucro 
TABELA 4 - ESTIMATIVA DO RENDIMENTO MÉDIO DE ALGUMAS EXPEDIÇÕES NEGREIRAS DO RIO DE JANEIRO EM 1812

\begin{tabular}{l|l|c|c|c|c|c|c}
\hline \multicolumn{1}{c|}{ Navio } & $\begin{array}{c}\text { Porto africano } \\
\text { de compra }\end{array}$ & $\begin{array}{c}\# \text { de } \\
\text { escra- } \\
\text { vos ad- } \\
\text { quiridos }\end{array}$ & $\begin{array}{c}\text { Investi- } \\
\text { mento } \\
\text { total } \\
\text { (em réis) }\end{array}$ & $\begin{array}{c}\% \text { de } \\
\text { escra- } \\
\text { vos } \\
\text { mortos }\end{array}$ & $\begin{array}{c}\text { \# de escra- } \\
\text { vos vendi- } \\
\text { dos no Rio } \\
\text { de Janeiro }\end{array}$ & $\begin{array}{c}\text { Produto da } \\
\text { venda } \\
\text { (em réis) }\end{array}$ & $\begin{array}{c}\text { Renta- } \\
\text { bilidade } \\
\text { bruta } \\
(\%)\end{array}$ \\
\hline Mercúrio & Benguela & 404 & $27: 270 \$ 000$ & 5.0 & 384 & $39: 936 \$ 000$ & +46.4 \\
Feliz Dia & Moçambique & 235 & $12: 690 \$ 000$ & 5.1 & 223 & $23: 192 \$ 000$ & +82.8 \\
S.José Americano & Benguela & 547 & $36: 922 \$ 000$ & 5.7 & 516 & $53: 664 \$ 000$ & +45.3 \\
Carolina & Benguela & 571 & $38: 542 \$ 500$ & 6.1 & 536 & $55: 744 \$ 000$ & +44.6 \\
Providente & Moçambique & 247 & $13: 338 \$ 000$ & 7.3 & 229 & $23: 816 \$ 000$ & +78.6 \\
N.S. Conceição & Luanda & 478 & $44: 525 \$ 700$ & 7.9 & 440 & $45: 760 \$ 000$ & +2.8 \\
Canoa & Luanda & 534 & $49: 742 \$ 100$ & 10.9 & 476 & $49: 504 \$ 000$ & -0.5 \\
M. Dafne & Luanda & 572 & $53: 281 \$ 800$ & 11.5 & 506 & $52: 624 \$ 000$ & -1.2 \\
Fiança & Luanda & 473 & $44: 059 \$ 950$ & 12.5 & 414 & $43: 056 \$ 000$ & -2.3 \\
Flor do Mar & Luanda & 462 & $43: 035 \$ 300$ & 12.6 & 404 & $42: 016 \$ 000$ & -2.4 \\
Feliz Indiana & Luanda & 462 & $43: 035 \$ 300$ & 12.6 & 404 & $42: 016 \$ 000$ & -2.4 \\
Guadalupe & Benguela & 458 & $30: 915 \$ 000$ & 15.9 & 385 & $40: 040 \$ 000$ & +29.5 \\
Julia & Luanda & 500 & $46: 575 \$ 000$ & 16.0 & 420 & $43: 680 \$ 000$ & -6.2 \\
Protector & Luanda & 397 & $36: 980 \$ 550$ & 38.0 & 246 & $25: 584 \$ 000$ & -30.8 \\
\hline
\end{tabular}

FONTE: FLORENTINO Manolo. Em Costas Negras: uma história do tráfico de escravos entre a África e o Rio de Janeiro (Séculos XVIII e XIX). São Paulo: Companhia das Letras, 1997, p. 171.

A tabela 4 indica os níveis de lucratividade alcançados em 14 expedições do Rio de Janeiro a Luanda, Benguela e Moçambique em 1812. Sabemos que neste ano o preço médio dos africanos no mercado carioca era de $104 \$ 000$ réis e que eles custavam $69 \$ 000$ réis em Luanda, $50 \$ 000$ réis em Benguela e 40\$000 réis na Ilha de Moçambique. De posse destes dados, poderíamos pensar que a lucratividade aumentava na medida em que os preços nas áreas de compra fossem baixos. Afinal, não é certo que os maiores lucros eram obtidos por expedições enviadas a Benguela e Moçambique, onde os preços dos escravos eram bem menores do que em Luanda?

Tais dados nada mais fazem do que reiterar a estratégia traficante de atuar na oferta por preços mais baixos. O passo seguinte seria multiplicálos através do aumento do volume de compras. Ora a coluna 3 da tabela 4 indica que a média de escravos por navio nas áreas onde os cativos eram mais baratos (Benguela e Moçambique) é de 410, bem menor do que a ve- 
rificada para os barcos que operavam em Luanda, 485. Pode-se argumentar que os traficantes que atuavam neste último porto resolveram compensar o maior preço ali cobrado incrementando a quantidade de africanos a serem adquiridos. Isto seria razoável a não ser por um pequeno detalhe: enquanto as viagens realizadas para Benguela e Moçambique conheceram altos níveis de lucratividade, quase todas as que se destinaram a Luanda acumularam prejuízos. Um paradoxo?

Em absoluto. A resposta está na coluna 5, que mostra haver uma relação inversamente proporcional entre as taxas de mortalidade durante a travessia e os lucros auferidos em cada viagem. Então: quanto maior a mortalidade, menor o lucro e, pelo contrário, menores "perdas em trânsito" significavam maiores rendimentos finais. Basta ver que se em todas essas viagens a mortalidade fosse zero, nenhuma expedição, independentemente da elasticidade do diferencial de preços com o qual trabalhasse, redundaria em prejuízo.

Creio que a chave para a compreensão da rentabilidade negreira resida no equilíbrio entre o investimento inicial em bens para o escambo (que determinaria o volume das aquisições) e as mercadorias para o abastecimento da escravaria (que determinaria baixos índices de mortalidade). Sabe-se que alguns traficantes se equivocaram neste cálculo, perdendo muitos escravos e se arruinando. Os tradicionalmente estabelecidos no circuito atlântico, porém, levavam consideráveis vantagens. Ao manterem uma relação mais estreita com os intermediários africanos, eles podiam obter escravos mais saudáveis e a melhores preços, pelos quais exigiam mais no mercado carioca. Por outro lado, ao disporem de maiores recursos, estavam mais aptos tanto à compra do maior número de cativos quanto à sua manutenção. Por isto é que, buscando diminuir estes últimos gastos e, ao mesmo tempo, a mortalidade da escravaria, recomendavam aos seus capitães que a negociação e travessia fossem feitas na maior brevidade possível. Não é gratuito, portanto, que eles operassem com as menores taxas de perda do tráfico atlântico $-6.5 \%$ contra os $10 \%$ de taxa geral.

Lembremos que, embora fundamentais, os gastos dos traficantes não se restringiam às mercadorias do escambo - incluíam os alimentos que mantinham a escravaria e a tripulação, o pagamento pelo desgaste dos equipamentos, os salários dos tripulantes, os direitos alfandegários e outras despesas eventuais. A soma do investimento total nestes itens, subtraída do 
que se obtinha com a venda dos escravos no mercado carioca, nos permitiu chegar a níveis médios de rendimento líquido no comércio Luanda-Rio de $16 \%$ para $1810,3 \%$ para $1812,6 \%$ para $1815,23 \%$ para 1817 e $44 \%$ para 1820. Lucrava-se em média nesta década algo em torno de $19 \%$ sobre o capital investido ${ }^{42}$.

São números muito significativos. A lucratividade média de 19\% é superior à de qualquer tráfico já estudado antes de 1830. É maior, por exemplo, do que a do comércio britânico de escravos (9.5\%), do que a do tráfico francês (10\%) e do que a do tráfico holandês (apenas 2.9\%). Por fim, a envergadura desta lucratividade superava a normalmente conseguida nos negócios do Antigo Regime europeu, que girava ao redor de 5\%, e também o lucro líquido médio sobre o capital anualmente investido para a reprodução das grandes fazendas escravistas do Rio de Janeiro, da Bahia e mesmo de certas regiões do Caribe (entre 5\% e 10\%). Tratava-se de um verdadeiro El Dorado - para aqueles que dele pudessem participar. Entretanto, o tráfico carioca era marcado por variações muito pronunciadas de sua rentabilidade: em média, de $3 \%$ a $44 \%$ sobre o investimento inicial. Tal amplitude é a outra face de um negócio cujas frenéticas mudanças explicam não somente a forte presença de especuladores durante as fases de expansão, mas também sua imediata retirada em épocas de crise. Ritmos tão violentos denotam um mercado estruturalmente instável e atrofiado - e por si mesmo arriscado. Isso fazia com que o traficante tradicional, o típico comerciante de homens da virada do século XVIII para o XIX, fosse acima de tudo um empresário com investimentos em vários setores.

\section{Tráfico e mercado colonial}

De 1796 a 1812, sem considerar as remessas de metais preciosos para a Metrópole, a tendência foi de sucessivas perdas da praça colonial

42 Trabalhando com uma metodologia distinta, David Eltis (Economic growth and the ending of the transatlantic slave trade. New York: Oxford Academic Press, 1987, p. 281) postula níveis de lucratividades próximos aos nossos para o tráfico cubano em 1826-35 (19.6\%) e 1836-45 (19.2\%) e para o tráfico brasileiro ao sul da Bahia em 1831-40 (17.8\%) e 1841-50 (21.8\%). 
fluminense em seu comércio com Lisboa ${ }^{43}$. Somente entre 1810 e 1812 o saldo negativo alcançou 267:040\$755 réis ${ }^{44}$. Também em relação a Goa o comércio carioca era deficitário, redundando em perdas que somavam 1:106:640\$220 réis nestes três anos. Viu-se que da Ásia adquiriam-se, sobretudo, fazendas, pagas mediante moeda sonante, o mais importante item das exportações do Rio para a Índia ${ }^{45}$. É possível que $10 \%$ do que o Rio importava da Ásia, 20\% do que vinha de Portugal e 30\% das compras efetuadas junto a outros países da Europa se destinassem ao tráfico que, desse modo, contribuía substancialmente para os déficits cariocas. Igualmente com relação à África, os déficits cariocas eram uma constante ao longo do século XVIII. Entretanto, o gráfico 3 mostra que, com o advento do Oitocentos, eles tornaram-se substancialmente menores, embora se reiterassem. Tal mutação se explica pela afirmação da praça mercantil do Rio de Janeiro como grande centro re-exportador de diversos bens produzidos em Portugal, noutros países europeus e mesmo na Ásia. No fundamental, apenas juntou-se em um mesmo espaço o eixo do fluxo de mercadorias que viabilizavam o escambo escravista e a comunidade mercantil que o financiava.

Só entre 1810 e 1812 as perdas do Rio de Janeiro frente ao continente negro somaram 459:574\$479 réis. A diferença continuava a ser paga com ouro amoedado que, por certo, não aparece nos registros das alfândegas africanas, embora constem dos rascunhos dos funcionários das mesmas ${ }^{46}$. Mas, afirmar o controle do circuito negreiro pelos traficantes da praça mercantil do Rio implica, necessariamente, em redefinir estas perdas, pois a diminuição dos

43 Cf. FRAGOSO, João; FLORENTINO, Manolo. A comunidade de mercadores do Rio de Janeiro e o mercado atlântico português na passagem do século XVIII para o XIX. In: BASTOS, Cristiana; ALMEIDA, Miguel Vale de; FELDMAN-BIANCO, Bela (Orgs.). Trânsitos coloniais: diálogos lusobrasileiros. Lisboa: Imprensa de Ciências Sociais, 2002, p. 321-342. Cf. também ARRUDA, José J. $O$ Brasil no comércio colonial. São Paulo: Ática, 1980, tabelas 17 e 19.

44 Resumo dos Mappas..., op. cit.

45 Entre 1810 e 1812, os panos representavam 98\% das importações cariocas junto a Goa e o ouro amoedado variava entre $79 \%$ e $98 \%$ das exportações do Rio para a Índia. Cf. Resumo dos Mappas..., op. cit., e também FRAGOSO, João; FLORENTINO, Manolo. Negociantes, mercado atlântico e mercado regional (estrutura e dinâmica da Praça Mercantil do Rio de Janeiro entre 1790 e 1812). In: FURTADO, Júnia Ferreira (Org.). Diálogos oceânicos (Minas Gerais e as novas abordagens para uma História do Império Ultramarino Português). Belo Horizonte: Editora UFMG, 2001, p. 155-179.

46 Por exemplo, nos registros da alfândega de Luanda consta que "Neste Reino também entraram bastantes porções de dinheiro em ouro, que alguns Comissários trazem do Brasil para compra de escravos" - cf. Balanço da importação e exportação deste Reino de Angola desde o anno de 1785, em que teve princípio o estabelecimento da alfândega, até o anno de 1794, inclusive. Arquivo do Instituto Histórico e Geográfico Brasileiro (RJ), Seção dos Manuscritos, lata 77, documento 1. 


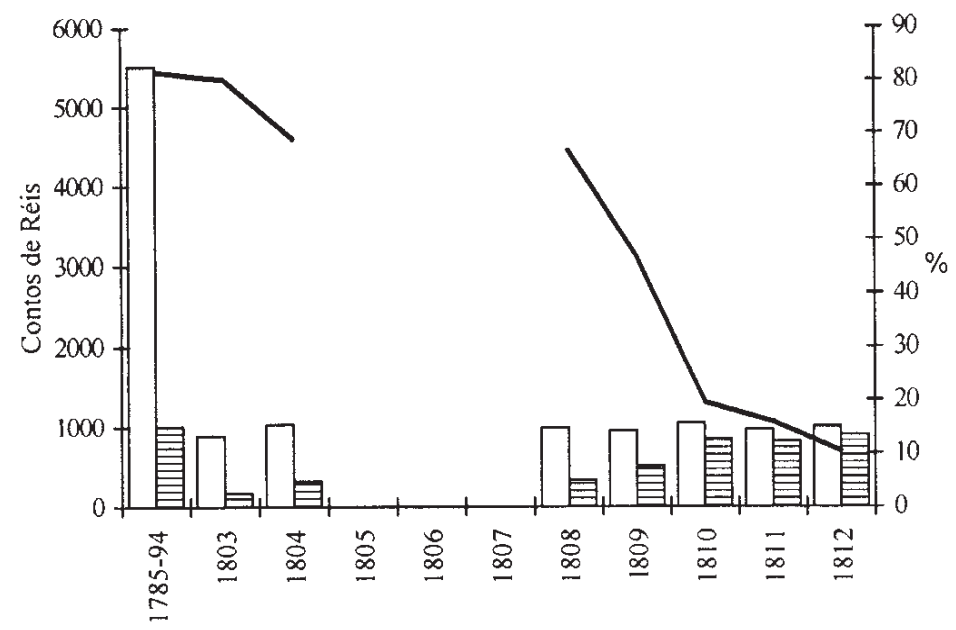

$\square$ Exportaçāo

Obs.: O movimento comercial de 1785 a 1794 abarca as exportações registradas para todo o Brasil (o que neste caso equivale basicamente ao Rio de Janeiro).

FONTES: a mesma do gráfico 1 acrescida do Resumo dos Mappas de Importação e Exportação... 1808-1814. Arquivo Nacional, Junta do Comércio, caixa 448, pacote 1.

déficits cariocas para com a África não significou o arrefecimento das perdas da comunidade de traficantes para com o exterior. Ao contrário, pois se, com o século XIX, os manufaturados aumentaram a sua participação nos produtos que constituíam o escambo, e se eles eram importados junto à Ásia e à Europa, é fácil aceitar terem igualmente crescido os déficits da comunidade de traficantes para com estas áreas. Entretanto, a revenda de africanos no mercado colonial mais do que compensava as perdas acumuladas pelos traficantes para com o exterior: os déficits transmutavam-se em lucro quando da distribuição dos cativos africanos no sul-sudeste brasileiro. Neste sentido, aliás, não é gratuito que a quitação das crônicas dívidas assumidas pelos traficantes para com Goa, Europa e África se desse fundamentalmente em dinheiro: 
tratava-se de numerário acumulado pelos traficantes da praça carioca a partir das revendas de cativos no Brasil ${ }^{47}$. Vejamos este processo mais de perto.

As balanças comerciais e os inventários post-mortem do início da década de 1810 permitem ter uma ideia da envergadura do volume de recursos movimentados pelas redes que comerciavam com os africanos recém-chegados (boçais). Trabalha-se aqui com a redistribuição destes boçais a partir do porto do Rio de Janeiro para a própria capitania do Rio de Janeiro e para Minas Gerais, Santos e Rio Grande do Sul.

Na tabela 5, os dados relativos ao volume de africanos revendidos para o porto de Santos e Rio Grande do Sul foram retirados diretamente do Resumo dos Mappas de Importação e Exportação pertencente ao acervo da Junta do Comércio (Arquivo Nacional). Assumimos que o Rio de Janeiro - a capital e o agro - tenha consumido metade dos africanos provenientes de Luanda e Benguela. Por outro lado, não dispomos de números relativos às reexportações de africanos para Minas Gerais, mas sabemos que esta capitania, além de aparecer nas estimativas demográficas de 1819 como a maior concentradora de escravos do Brasil, recebia mais de $40 \%$ dos africanos desembarcados no porto do Rio de Janeiro na década de $1820^{48}$. Consideramos que algo próximo a este perfil possa ter prevalecido para os anos de 1810-1812, assumindo, portanto, que para Minas se dirigiam os escravos restantes.

Os preços dos africanos na África (63\$938 réis em média para os três anos) constam dos mencionados Resumos, do mesmo modo que os seus valores em Santos e no Rio Grande do Sul - respectivamente, 128\$000 réis e 133\$255 réis em média. Configuravam-se nestes casos lucratividades brutas médias de mais de $100 \%$. Com relação a Minas Gerais, em suas Memórias do Distrito Diamantino, Joaquim Felício dos Santos afirma que em fins do século 18 comprava-se escravos no Rio de Janeiro por algo entre

47 Discorrendo sobre as enormes exportações de metais preciosos do Rio para Lisboa entre 1763 e 1808, Corsino Medeiros dos Santos afirma que "essa sangria [de moedas do Rio para o Reino] só não teria levado o comércio carioca ao colapso porque as moedas cunhadas noutras capitanias também tinham aí livre trânsito; além disso, nas Minas Gerais, Mato Grosso e Goiás, e até mesmo no burgo carioca em algumas ocasiões, circulava o ouro em pó, apesar das muitas restrições" (cf. Relações comerciais do Rio de Janeiro com Lisboa. Rio de Janeiro: Tempo Brasileiro, 1980, p. 192-195).

48 FRAGOSO, João. Homens de grossa aventura. Rio de Janeiro: Civilização Brasileira, 1998, p. 177; e IBGE, op. cit., p. 30. 


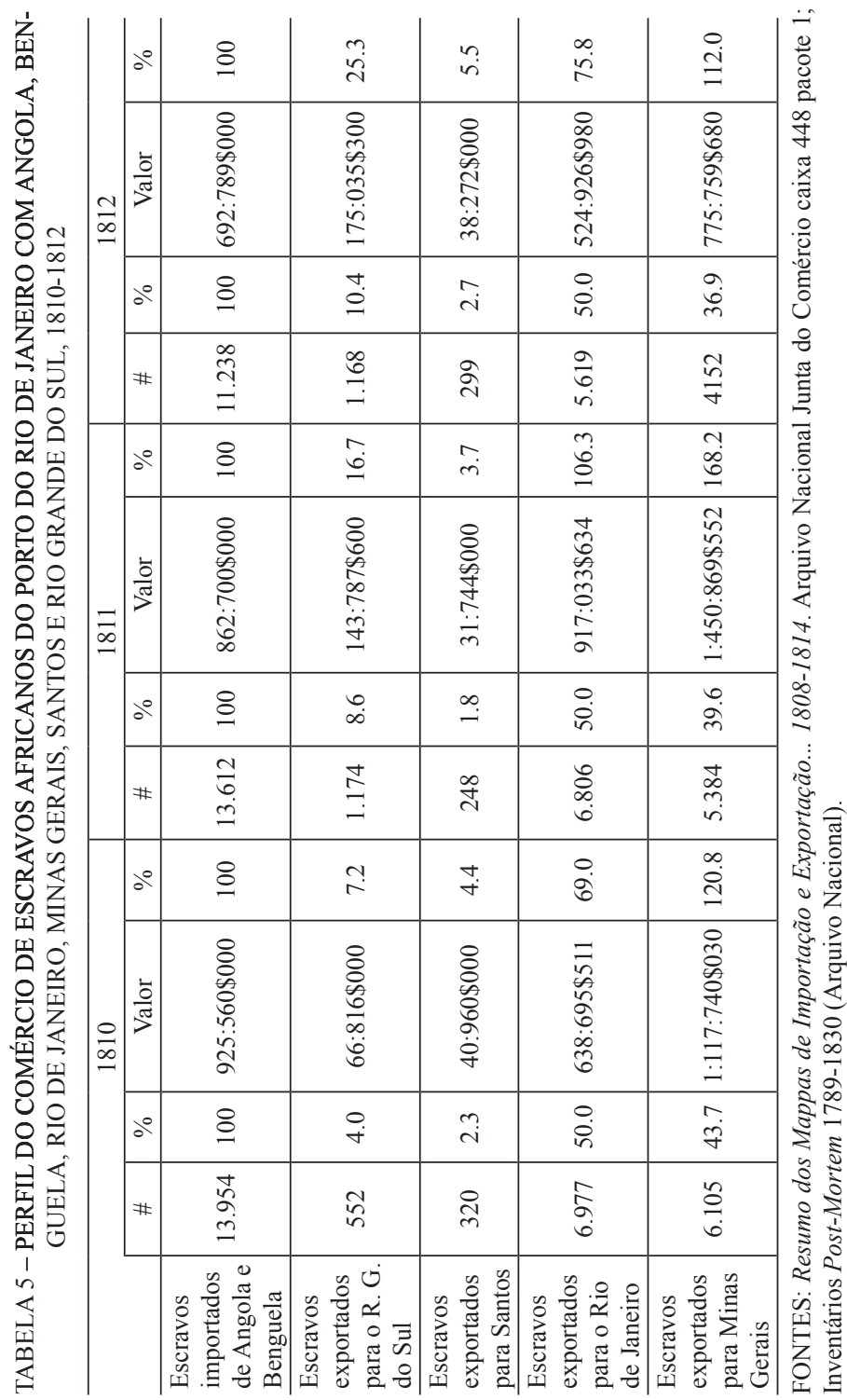


$100 \$ 000$ e $120 \$ 000$ réis, e que estes eram logo revendidos em Minas por até $240 \$ 000$ réis $^{49}$. É possível que tal padrão tenha se mantido na virada da década de 1800 para a seguinte, o que nos faculta assumir que a diferença entre o valor de compra dos escravos na África e o de sua venda nas Gerais gerasse lucros brutos de mais de $100 \%$. Por fim, os preços médios de escravos africanos entre 14 e 40 anos de idade no Rio de Janeiro, calculados a partir das listagens de escravos constantes de inventários post-mortem, eram de $91 \$ 500$ réis para $1810,135 \$ 000$ réis para 1811 e $93 \$ 400$ réis para o ano seguinte - numa média de $107 \$ 239$ réis, o que, frente ao custo dos africanos em Angola, significa lucros brutos de quase $60 \%$.

Embora o Rio Grande do Sul e Santos absorvessem juntos, em $1810-1812$, de $6 \%$ a $13 \%$ dos escravos adquiridos pelo porto carioca na África, o valor das reexportações destes boçais variava de $11 \%$ a $31 \%$ do total das compras de escravos realizadas pelo Rio de Janeiro em Luanda e Benguela. $\mathrm{O}$ que se obtinha apenas com a diferença entre o preço de compra na África e o de revenda destes boçais para Santos e Rio Grande (duas áreas periféricas da colônia, note-se) era quase 10\% maior do que todo o déficit acumulado pelo Rio de Janeiro com a África ao longo de 1810-1812 (459:574\$479 réis). Nestes mesmos anos, o bruto amealhado com a revenda no próprio Rio de Janeiro era quase dez vezes maior do que o déficit acumulado para com Portugal (267:040\$755 réis, sem considerar ouro e prata), e o gerado pela revenda para Minas Gerais era três vezes maior do que as perdas acumuladas para com a Índia (1:105:640\$220 réis).

Globalmente falando, os 5:921:640\$287 réis brutos amealhados com as revendas para Santos, Rio Grande, Minas Gerais e para o próprio Rio de Janeiro representavam uma cifra 3.3 vezes superior à soma dos déficits acumulados pelo Rio de Janeiro para com a Metrópole, África e Ásia (1:832:255\$454 réis). Alcançavam também um valor três vezes superior ao obtido com as exportações de açúcar para Portugal entre 1810 e 1812 (1:913:711\$000 réis $)^{50}$. Este último dado indica que os valores gerados pelas revendas de escravos para o sul-sudeste, ao somarem uma quantia três vezes superior àquelas produzidas pelas exportações da plantation, transformavam

49 SANTOS, Joaquim Felício dos. Memórias do distrito diamantino. Petrópolis: Vozes/Instituto Nacional do Livro, 1978, p. 282-283.

50 Quadros Financeiros..., op. cit., e Resumo dos Mappas..., op. cit. 
o Rio de Janeiro em uma praça mercantil que tinha nas exportações um setor secundarizado frente ao que se lograva realizar no âmbito de reexportações de africanos para o mercado interno colonial.

As revendas de cativos teciam uma ampla rede cujo eixo era representado pelo capital mercantil carioca. Seu âmbito abarcava dos confins dos sertões brasileiros até portos como Rio Grande, Desterro e Paranaguá. Não é absurdo postular que a maior parte dos ganhos do capital traficante do Rio de Janeiro proviesse desta rede. O lucro sobre a alienação aparece, portanto, como uma espécie de vocação da comunidade negreira residente, caracterizada no seu topo por empresários voltados para a atuação monopolística e simultânea em diversos setores de negócios. Tratava-se de uma forte elite mercantil, controladora de gigantescas operações de natureza atlântica.

Observe-se, porém, que, estivesse nos pampas rio-grandenses, no planalto paulista ou nas Gerais, era o comprador das reexportações cariocas de escravos quem, mediante moeda sonante e/ou créditos, viabilizava o pagamento dos déficits cariocas para com a Metrópole, a África e a Ásia. E o fazia, no limite, não exatamente através da produção voltada para o mercado internacional ou para outras partes do império português, mas sim mediante a realização regional de inúmeras outras mercadorias. Refirome, com efeito, às farinhas, carnes salgadas, porcos, muares e demais que eram produzidos e vendidos não apenas às plantations em expansão, mas também aos mercados locais. Tratava-se de incontáveis trocas cotidianas, efetuadas em meio a uma multidão de pequenos e médios produtores, cujo somatório era superior ao setor mais lucrativo e especializado da economia colonial - a monocultura agroexportadora. Redefine-se, assim, certa imagem da sociedade colonial que associa de forma indelével o colono ou bem ao senhor de muitos escravos ou apenas ao homem pobre que, marginalizado da plantation, viveria praticamente fora do mercado, dedicado a uma produção de subsistência que beiraria a economia natural ${ }^{51}$. 


\section{Tráfico, escravidão e famílias escravas}

Embora o porto do Rio de Janeiro se constituísse em um importante centro de redistribuição de africanos para todo o centro-sul brasileiro, parte expressiva desses escravos recém-desembarcados permanecia na capitania. Eis por que, com o crescimento do tráfico, a participação dos africanos entre os cativos listados em inventários post-mortem do agro fluminense - doravante taxa de africanidade - saltou de quase $50 \%$ entre 1789 e a chegada ao Brasil da Corte lisboeta (1808), para 60\% entre 1810 e 1832. Nos inventários do meio urbano, entre os mesmos intervalos, a africanidade passou de $65 \%$ para $79 \%$.

TABELA 6 - DISTRIBUIÇÃO DOS ESCRAVOS DO RIO DE JANEIRO POR GRANDES GRUPOS ETÁRIOS E SEXO, 1789-1832

\begin{tabular}{|c|c|c|c|c|c|c|c|c|c|c|c|c|c|}
\hline & \multirow{3}{*}{$\begin{array}{l}\text { Grandes } \\
\text { faixas } \\
\text { etárias }\end{array}$} & \multicolumn{6}{|c|}{ 1789-1808 } & \multicolumn{6}{|c|}{$1810-1832$} \\
\hline & & \multicolumn{3}{|c|}{ Crioulos } & \multicolumn{3}{|c|}{ Africanos } & \multicolumn{3}{|c|}{ Crioulos } & \multicolumn{3}{|c|}{ Africanos } \\
\hline & & A & B & $\mathrm{C}$ & A & B & $\mathrm{C}$ & $\mathrm{A}$ & B & $\mathrm{C}$ & A & B & $\mathrm{C}$ \\
\hline \multirow{3}{*}{$\begin{array}{l}\text { Meio } \\
\text { rural }\end{array}$} & $0-14$ anos & 53,3 & 55,1 & 497 & 3,0 & 76,0 & 25 & 53,5 & 51,9 & 916 & 6,6 & 65,1 & 166 \\
\hline & $15-40$ anos & 37,8 & 49,1 & 352 & 66,6 & 60,0 & 560 & 36,5 & 54,8 & 626 & 71,8 & 69,8 & 1809 \\
\hline & +40 anos & 8,9 & 51,8 & 83 & 30,4 & 71,0 & 255 & 100 & 55,8 & 172 & 21,6 & 71,1 & 546 \\
\hline \multirow{3}{*}{$\begin{array}{l}\text { Meio } \\
\text { urbano }\end{array}$} & 0-14 anos & 53,0 & 44,7 & 132 & 7,2 & 70,6 & 34 & 55,8 & 54,0 & 285 & 9,2 & 67,2 & 174 \\
\hline & $15-40$ anos & 41,4 & 52,4 & 103 & 70,7 & 64,9 & 333 & 38,4 & 49,0 & 196 & 74,3 & 67,2 & 1398 \\
\hline & +40 anos & 5,6 & 50,0 & 14 & 22,1 & 71,2 & 104 & 5,8 & 63,3 & 30 & 16,5 & 73,2 & 310 \\
\hline
\end{tabular}

A - \% de escravos da grande faixa etária frente ao total de escravos

B - Taxa (\%) de masculinidade na grande faixa etária

C - Número de escravos

FONTES: As mesmas da tabela 1.

A tabela 6 igualmente indica que, em função dos desequilíbrios etário-sexuais derivados do comércio negreiro, os escravos do Rio de Janeiro somente podiam se reproduzir adequadamente por meio do fluxo externo de africanos. O tráfico tornava absoluto o predomínio dos adultos na população escrava - entre 1789 e 1832 eles sempre perfizeram mais da metade dos cativos, proporção que chegou a abarcar dois entre cada três escravos que habitavam as cidades. Embora majoritários, os adultos eram bastante desequilibrados em termos de gênero, com o predomínio masculino chegando a alcançar uma proporção de dois homens para cada mulher. De todo modo, as crianças não eram suficientes para substituí-los no tempo. 
Em que pese tais determinantes, não se deve elidir a alta participação das crianças crioulas, cujo contingente era, independentemente da conjuntura do tráfico e do meio considerado, sempre superior à metade dos escravos nascidos no Brasil ${ }^{52}$. Tratava-se, é certo, do efeito mais evidente da exiguidade da expectativa de vida, o que pode ser aferido pelos poucos crioulos que alcançavam mais de quarenta anos de idade (10\% do total no máximo). Mas era também resultante do esforço dos próprios escravos para reverter o desarraigo próprio de uma população marcada por alto grau de estrangeirismo, para o que as práticas que permitiam às famílias escravas se refazerem eram de fundamental importância.

No Brasil, até bem pouco tempo era impossível tomar a vida familiar escrava como um legítimo objeto de reflexão, pois afirmava-se que promiscuidade e desregramento social seriam traços marcantes das escravarias. Ademais, família e tráfico atlântico se excluiriam, pois o fluxo externo de almas, com o seu marcante desequilíbrio sexual, impossibilitaria aos escravos a criação de estratégias parentais eficazes.

Os inventários post-mortem do meio rural fluminense permitem abordar a família escrava somente naqueles a partir de grupos parentais primários - pais e filhos, esposos sem filhos ou, ainda, apenas um dos pais e suas respectivas proles. Cremos, porém, ser este material suficientemente rico para demonstrar que os argumentos dos clássicos não se sustentam, indicando, de início, a compatibilidade entre vida familiar e tráfico atlântico. Logo depois, assinalaremos a presença de alguns importantes padrões culturais (a saber, regras sociais como a urgência em estabelecer laços parentais, a endogamia matrimonial por naturalidade e o predomínio dos escravos mais velhos no mercado matrimonial) mediante os quais os cativos continuamente construíam e reconstruíam sua vida familiar.

Por se tratar de uma população que se alimentava fundamentalmente das entradas de africanos, é razoável aceitar que as relações familiares escravas, os seus tipos de arranjos e, mesmo, os padrões socioculturais que realizavam a socialização parental também flutuassem ao sabor dos movimentos do tráfico negreiro. Tais padrões e atitudes serão analisados de acordo

52 CAVALCANTI, op. cit., mostra que entre $1687 \mathrm{e} 1809$ as "crianças" correspondiam a tão somente $17 \%$ da população do Rio de Janeiro. Embora houvesse entre elas um pequeno desequilíbrio a favor dos meninos, era entre os adultos e idosos que a desproporção sexual era realmente grande (64\% de taxa de masculinidade). Sua amostragem se compõe de 1.236 escravos, retirados de 60 inventários post-mortem. 
com os três grandes intervalos em que dividimos o período 1790-1830: uma fase de estabilidade dos desembarques (1790-1808), que chamaremos de fase B do tráfico, outra de aceleração (1809-1825), designada por fase A, e outra mais, de crise da oferta africana de homens (1826-1830).

De acordo com a tabela 7 , em épocas de estabilidade do tráfico os cativos aparentados representavam mais ou menos $1 / 3$ da escravaria, cifra que caía para $1 / 4$ na etapa de aceleração e, de novo, chegava a $1 / 3$ no período de crise do comércio negreiro. Nada mais previsível do que, na passagem da fase $\mathrm{B}$ para a fase $\mathrm{A}$, diminuísse o número de parentes, à causa da entrada maciça de indivíduos totalmente desprovidos de laços parentais. De maneira aparentemente paradoxal, entretanto, a etapa de crise da oferta - época de maior incremento dos desembarques - apresenta índices de parentesco semelhantes aos de momentos de estabilidade das entradas de africanos. É que, por então, sem que os homens deixassem de ser maioria entre os cativos adquiridos, os grandes plantéis crescentemente incorporavam maior quantidade de mulheres escravizadas. Em épocas de incerteza quanto à continuação ou não do tráfico, junto com a capacidade produtiva dos escravos valorizava-se a capacidade reprodutora da mulher cativa.

Um outro aspecto a chamar a atenção na tabela 7 é a grande porcentagem (entre $65 \%$ e $75 \%$ ) de escravos não atados a relações parentais primárias. É possível que documentos mais ricos em informações permitissem detectar outras condições parentais (avós, netos, tios, sobrinhos, primos e, mesmo, padrinhos e madrinhas), o que aumentaria para algo em torno de $50 \%$ ou $60 \%$ as taxas de escravos unidos pelo parentesco.

TABELA 7 - VARIAÇÃO DAS TAXAS (\%) DE CRESCIMENTO MÉDIO ANUAL DO TRÁFICO E DAS TAXAS (\%) DE PARENTES DE PRIMEIRO GRAU NOS PEQUENOS (DE 1 A 9 ESCRAVOS), MÉDIOS (DE 10 A 19 ESCRAVOS) E GRANDES (+ DE 20 ESCRAVOS) PLANTÉIS DO AGRO DO RIO DE JANEIRO, 1790-1830

\begin{tabular}{l|c|c|c|c|c|c|c|c|c}
\hline & \multicolumn{3}{|c|}{$1790-1808$} & \multicolumn{3}{c|}{$1809-1825$} & \multicolumn{3}{c}{$1826-1830$} \\
\hline $\begin{array}{l}\text { Faixa de } \\
\text { tamanho de } \\
\text { plantel }\end{array}$ & $\begin{array}{c}1-9 \text { es- } \\
\text { cravos }\end{array}$ & $\begin{array}{c}10-19 \\
\text { escra- } \\
\text { vos }\end{array}$ & $\begin{array}{c}+ \text { de } \\
20 \text { es- } \\
\text { cravos }\end{array}$ & $\begin{array}{c}1-9 \\
\text { escra- } \\
\text { vos }\end{array}$ & $\begin{array}{c}10-19 \\
\text { escra- } \\
\text { vos }\end{array}$ & $\begin{array}{c}+ \text { de } \\
20 \text { es- } \\
\text { cravos }\end{array}$ & $\begin{array}{c}1-9 \text { es- } \\
\text { cravos }\end{array}$ & $\begin{array}{c}10-19 \\
\text { escra- } \\
\text { vos }\end{array}$ & $\begin{array}{c}+ \text { de } \\
20 \text { es- } \\
\text { cravos }\end{array}$ \\
\hline $\begin{array}{l}\text { \% de Paren- } \\
\text { tes de primei- } \\
\text { ro grau }\end{array}$ & 31.0 & 24.0 & 42.0 & 25.0 & 20.0 & 26.0 & 24.0 & 8.0 & 37.0 \\
\hline
\end{tabular}

FONTES: As mesmas da tabela 1. 
É difícil não aceitar que o número de escravos celibatários fosse alto, pois se sabe ter sido enorme a desproporção sexual imperante nos grupos de africanos recém-chegados. Mesmo diante de tão sério obstáculo, em todas as idades encontramos parentes escravos - cf. o gráfico 4 . A acentuada queda das relações parentais verificada para as crianças desde o nascimento até os 14 anos resultava das separações forçadas de seus pais (por venda ou divisão de heranças), de alforrias, de fugas ou da alta mortalidade. Esta queda era também expressão da cada vez mais acentuada incorporação de cativos africanos aos plantéis - isto é, repitamos, da chegada de escravos inicialmente sem vínculos parentais. Após os 15 anos de idade, entretanto, paulatinamente reconstruíam-se as redes de primeiro grau. Tal movimento é da maior importância, pois mostra que, em uma idade economicamente ótima, quando em tese mais coisificados deveriam ser, ao invés de perderem parentes os escravos os ganhavam. A socialização parental e o tráfico não eram variáveis totalmente excludentes.

GRÁFICO 4 - VARIAÇÃO DAS TAXAS (\%) DE AFRICANIDADE E DE PARENTES DE PRIMEIRO GRAU POR FAIXAS ETÁRIAS NO AGRO DO RIO DE JANEIRO, 1790-1830

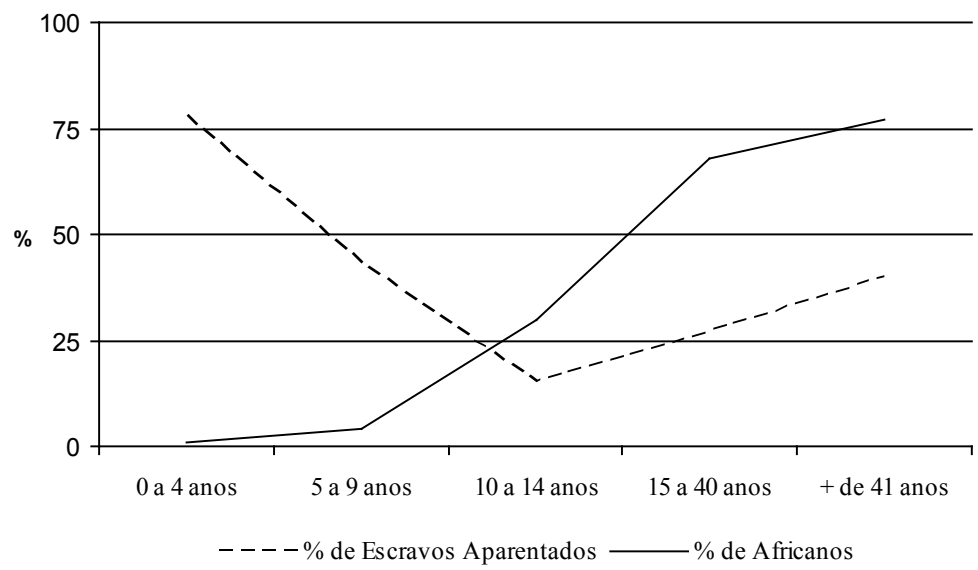

FONTES: As mesmas da tabela 7. 
Alguns tipos específicos de práticas culturais que permitiam ao parentesco não apenas se expressar, mas igualmente regrar-se. O primeiro deles: a urgência em estabelecer laços parentais traduzida, de início, pela busca constante do incremento de nascimentos e, em segundo lugar, pelo aumento das uniões consensuais entre escravos em determinadas conjunturas do tráfico.

Ser uma criança escrava era, no fundamental, sinônimo de haver nascido no Brasil. Uma exceção confirma esta regra: entre 1790 e 1830, encontramos nos inventários post-mortem somente uma família formada por mãe e filho africanos (a de Catarina Benguela, de 23 anos, cujo filho Manoel, de 4, também era da mesma etnia). No geral, os escravos menores de 14 anos de idade variavam, grosso modo, entre 1/4 e 1/3 da escravaria. Supomos que tenham sido desejados, pois a análise das fontes possibilitou entrever a já referida urgência da procriação cativa.

O primeiro indício desta urgência é que as cativas do agro fluminense começavam a procriar entre 14 e 17 anos de idade se crioulas fossem, e, se nascidas na África, entre os 16 e os 19 anos. Comparativamente falando, elas pariam mais cedo e por certo em condições muito mais adversas do que as mulheres livres coloniais (que tinham filhos logo depois dos 19 ou 20 anos), e mais cedo ainda do que as mulheres livres da Europa moderna (que pariam aos 25 anos aproximadamente). Isto indica um forte paralelismo entre os padrões de procriação inicial das escravas brasileiras e aqueles vigentes na África tradicional, onde a mulher casava e paria logo após a puberdade. Assim, é razoável supor que a incidência desta precocidade resultasse da transposição e posterior adequação de um padrão cultural de base africana.

As cativas concebiam a intervalos de aproximadamente dois ou três anos (seis meses a mais se africanas fossem), períodos bem maiores do que os vigentes entre as mulheres brancas brasileiras. É sintomático que as africanas concebessem a intervalos maiores do que as crioulas. Isto indica a permanência (quiçá redefinida para um pouco menos no Brasil) de um segundo padrão próprio da África, onde o prolongamento do período de amamentação poderia adiar por bem mais de três anos uma nova concepção.

Estamos agora diante de um quadro aparentemente contraditório: da tenra idade em que se iniciava o período reprodutivo deduzimos a busca, o mais cedo possível, de procriar, sugestão logo contrabalançada pela existência de longos períodos intergenésicos. Neste contexto, uma possível 
urgência sociológica pela procriação somente poderia se expressar se a grande intervalação entre os nascimentos fosse compensada pelas escravas parirem até muito tarde, isto é, praticamente tangenciando o limite superior de sua etapa sexualmente fértil. $\mathrm{E}$, realmente, os nossos dados indicam que o fim da procriação dava-se por volta dos 39 anos de idade, índice superior ao limite final de procriação africana. Isto significa que as escravas crioulas ou africanas podem ter redefinido o padrão africano, alongando-o (lá, as mulheres deixavam de parir por volta dos $31 / 33$ anos).

Em suma, as escravas pariam logo depois de púberes a intervalos de dois ou três anos, e alongavam ao máximo a idade de procriação do último filho. A procriação era, portanto, um objeto de investimento desta espécie de obsessão sociológica de aparentar-se e a sua maximização dependeu do exercício de certos padrões forjados pela vivência escrava. $\mathrm{O}$ alvo desta incessante busca do ventre gerador era recriar e tornar mais complexo justo o parentesco. Porque este pacificava e regrava os escravos.

Um segundo padrão comportamental detecta a urgência de estabelecer parentesco. Trata-se da subversão, em determinadas conjunturas do tráfico, da norma que na época colonial tornava legítima uma família: o casamento religioso. Tentaremos detectar este padrão analisando a frequência dos tipos de grupos familiares primários de acordo com as conjunturas do comércio negreiro. Para tanto, o gráfico 5 mostra que os casamentos tendiam a se realizar dentro da norma (isto é, com as uniões se submetendo à sanção religiosa) na fase $\mathrm{B}$ do tráfico. As famílias nucleares - sinônimos aqui de grupos constituídos por pais casados e seus filhos, ou os esposos sem filhos cujo matrimônio era legalmente sancionado - eram maioria e elas congregavam a maior parte dos parentes. Na medida em que o tráfico se incrementava, no entanto, a socialização parental tendia a se dar fora da norma e as famílias matrifocais (entendidas aqui como aquelas formadas por mães solteiras africanas ou crioulas e seus rebentos) tendiam a ser majoritárias.

A peculiar configuração que assumiam os núcleos familiares primários segundo a variação do tráfico nos coloca diante de mecanismos pelos quais, para além da violência, a estabilidade política da sociedade escravista se reproduzia. Dependente da constante incorporação de estrangeiros, o sistema escravista, para bem funcionar, requeria inúmeros dispositivos mediante os quais alcançava integrá-los a si. Porque regrava, o casamento era um deles, constituindo-se em poderoso agente de correção de hábitos e 
GRÁFICO 5 - VARIAÇÃO (\%) DAS FAMÍLIAS NUCLEARES E MATRIFOCAIS NO AGRO DO RIO DE JANEIRO, 1790-1830

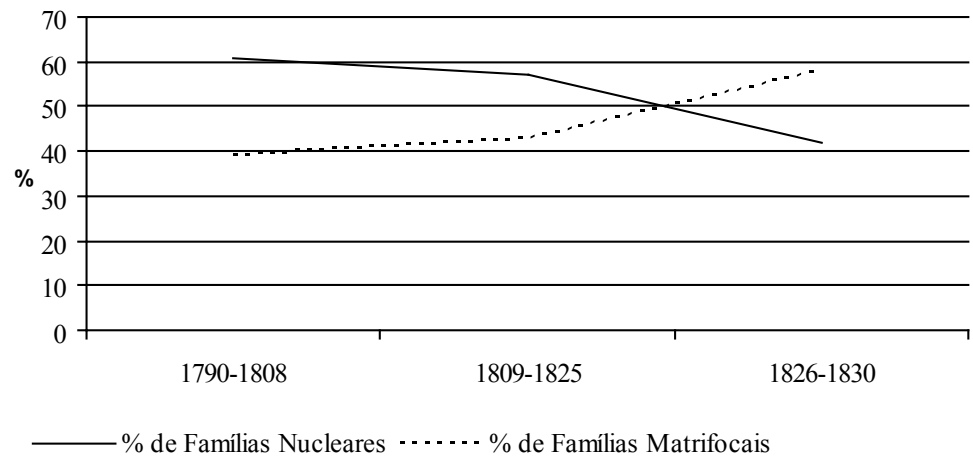

FONTES: As mesmas da tabela 7.

atitudes porventura inadequadas ao aprender a ser escravo. O matrimônio legal estava enfim preparado para funcionar adequadamente em momentos de estabilidade do tráfico, quando a participação relativamente menor de estrangeiros entre os escravos ainda permitia aos africanos utilizarem-se do casamento para a realização de seus anseios em se aparentarem. Em fases de expansão, contudo, os grupos matrifocais predominavam, isto é, a aculturação através do matrimônio dava sinais de exaustão. Do ponto de vista de um grupo de cativos agora altamente desarraigados, a união sancionada já não dava vazão à fome de aparentar-se, pelo que subvertia-se a norma. Predominavam, então, as uniões à margem da sanção religiosa.

Os matrimônios dos quais temos falado eram, dos laços parentais, os mais frequentes entre os escravos: de $30 \%$ a $40 \%$ de todos os parentes estavam casados, cifra que variava entre $50 \%$ e $57 \%$ considerando somente os cativos adultos. Tomando apenas os matrimônios legais, conclui-se que africanos e crioulos tinham acesso à sanção religiosa. Observe-se, no entanto, que eram sempre os primeiros os casais a predominar na realização deste tipo de matrimônio: casais africanos variavam de acordo com a conjuntura do tráfico, entre $56 \%$ e $67 \%$ de todos os casais (vejam o gráfico 6 ). 


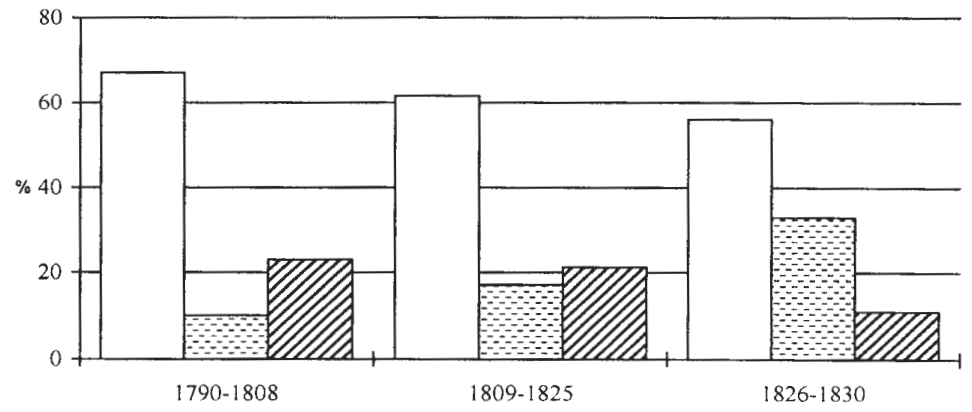

$\square$ Africanos X Africanos $\square$ Crioulos X Crioulos $\square$ Mistos

FONTES: As mesmas da tabela 7.

Por certo, a maior incidência de matrimônios sancionados entre os africanos é até certo ponto explicável por tenderem eles a serem majoritários entre os cativos maiores de 15 anos (aqueles estavam biologicamente aptos ao casamento). Entretanto, devido à alta taxa de masculinidade existente entre os adultos, seria de se esperar que os casamentos mistos tendessem a ser majoritários na medida em que aumentasse o volume de desembarques: afinal, frente à penúria de mulheres, os nascidos na África buscariam parceiras tanto entre as africanas quanto entre as crioulas. Não era isto, entretanto, o que ocorria, e o próprio gráfico 6 o demonstra, indicando que em épocas de maiores desembarques o número de casamentos mistos, ao contrário, tendia a declinar.

A conclusão é óbvia e revela mais uma prática que instituía o parentesco escravo: a escolha dos parceiros era presidida por um critério seletivo no que concernia à naturalidade. Assim, dependendo da conjuntura considerada, em cada grupo de dez casais, de cinco a sete eram formados por consortes africanos, de um a três eram formados por escravos nascidos no Brasil, e de um a dois uniam cônjuges africanos e crioulos. $A$ endogamia por naturalidade era a norma. Mas a variação temporal dos arranjos matrimoniais de acordo com as naturalidades nos ensina mais. Se 
o decréscimo da participação dos casais africanos no universo dos casais escravos não era concomitante a um crescimento das uniões mistas, isto significa que quanto maior era o volume do tráfico, maiores dificuldades tinham os africanos de realizar seus casamentos dentro da norma. Vimos um aspecto desta mudança mais acima, quando tratamos da variação dos tipos de agrupamentos familiares primários. A queda dos percentuais dos casamentos entre africanos e das uniões mistas só pode significar uma coisa: os crioulos tendiam a se fechar entre si. Nos momentos de expansão, pois, acirravam-se as rivalidades entre africanos e crioulos.

Descobrir os fundamentos desta rivalidade levou-nos ao encontro de mais um tipo de prática cultural que permitia que o parentesco escravo se expressasse. Detenhamo-nos sobre as diferenças médias entre as idades dos cônjuges por faixas etárias e naturalidade.

\section{GRÁFICO 7 - DISTRIBUIÇÃO DA DIFERENÇA ETÁRIA MÉDIA ENTRE OS CÔNJUGES ESCRAVOS AFRICANOS NO AGRO DO RIO DE JANEIRO, 1790-1808}

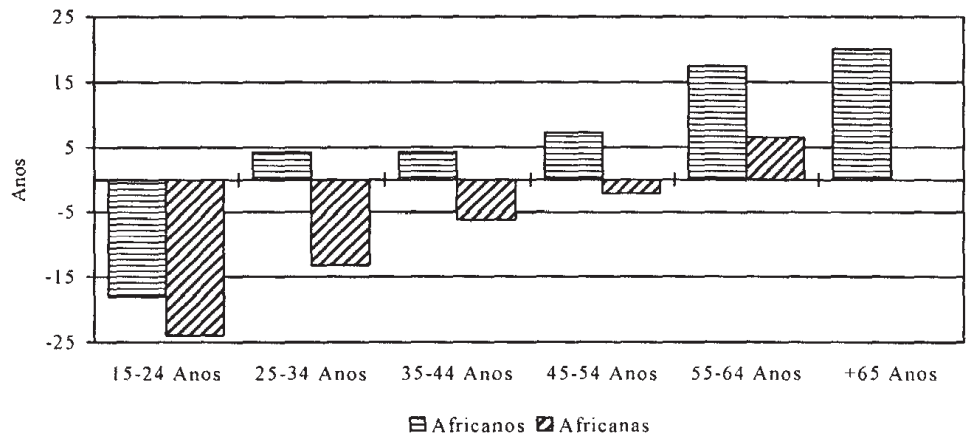

FONTE: Inventários Post-Mortem 1790-1808 (Arquivo Nacional). 
GRÁFICO 8 - DISTRIBUIÇÃO DA DIFERENÇA ETÁRIA MÉDIA ENTRE OS CÔNJUGES ESCRAVOS CRIOULOS NO AGRO DO RIO DE JANEIRO, 1790-1808

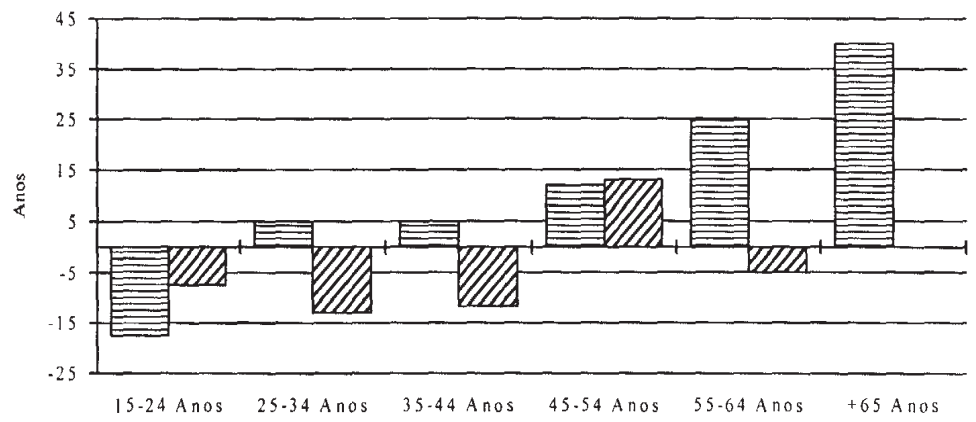

FONTE: Inventários Post-Mortem 1790-1808 (Arquivo Nacional).

Os gráficos 7 e 8 nos mostram que, nas épocas de estabilidade do tráfico, africanos e crioulos a partir dos 24 anos tendiam a ser crescentemente mais velhos do que suas esposas. Estas, por sua vez, eram mais novas que seus parceiros de forma decrescente dos 15 aos 45 anos. Ou seja, quanto mais velho era o cativo, maior a diferença etária entre ele e sua esposa; dito de outro modo, quanto mais nova esta fosse, maior a referida diferença para com o seu marido. Podemos pensar em um movimento tendencialmente simétrico, marcado por uma relação causal: se a diferença etária do homem aumentava com o tempo, sobretudo em se tratando de homens crioulos, era porque eles gradualmente se casavam com mulheres cada vez mais jovens. Em suma, em fases B dos desembarques de africanos, os mais velhos homens dominam o mercado de mulheres férteis. Nestes momentos, a competição entre os mais velhos parece ligeiramente desequilibrada em prol dos idosos nascidos no Brasil.

Observe-se que, curiosamente, encontramos a mesma simetria etária agora entre mulheres idosas (mais de 45 anos) e homens muito jovens (entre 15 e 25 anos): quanto mais velhas, maiores as diferenças etárias delas para com seus parceiros; estes, portanto, quanto mais jovens, mais novos que suas parceiras. O monopólio dos homens mais velhos era tão forte sobre as mulheres férteis que os cativos jovens eram permanentemente excluídos do acesso a estas últimas. Aos escravos muito jovens, particularmente aos 
nascidos na África, sobravam apenas as mulheres bem mais velhas. Ou seja, sob o domínio constante dos escravos mais velhos, à mulher escrava somente cabia a retomada de seu corpo quando este já não mais podia reproduzir. Estamos, portanto, longe de uniões conjugais ocorridas ao acaso, isto é, ao descompasso de regras culturalmente aceitas.

Mas o que se passava quando do incremento do tráfico, ocorrido depois de 1808? De acordo com os gráficos 9 e 10, em termos gerais passaram a ser menores as diferenças etárias entre homens jovens e suas esposas. Os jovens esposos africanos (de 15 a 24 anos) chegavam mesmo a ser mais velhos que suas mulheres. De algum modo, o incremento dos desembarques, até por significar a absorção de maiores contingentes de africanos não tão idosos, desarranjava ou dificultava o controle dos idosos sobre o mercado matrimonial.

GRÁFICO 9 - DISTRIBUIÇÃO DA DIFERENÇA ETÁRIA MÉDIA ENTRE OS CÔNJUGES ESCRAVOS AFRICANOS NO AGRO DO RIO DE JANEIRO, 1809-1830

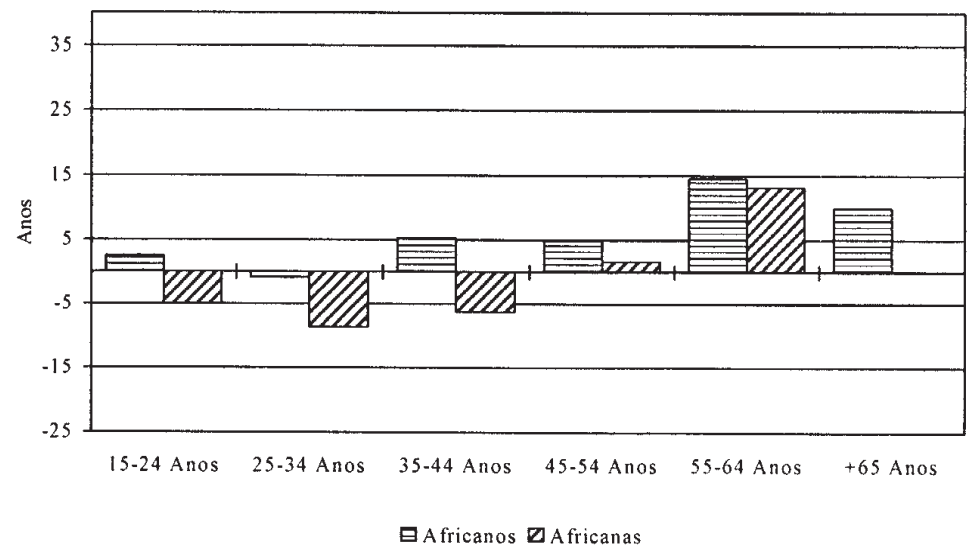

FONTE: Inventários Post-Mortem 1809-1830 (Arquivo Nacional). 


\section{GRÁFICO 10 - DISTRIBUIÇÃO DA DIFERENÇA ETÁRIA MÉDIAENTRE OS CÔNJUGES} ESCRAVOS CRIOULOS NO AGRO DO RIO DE JANEIRO, 1809-1830

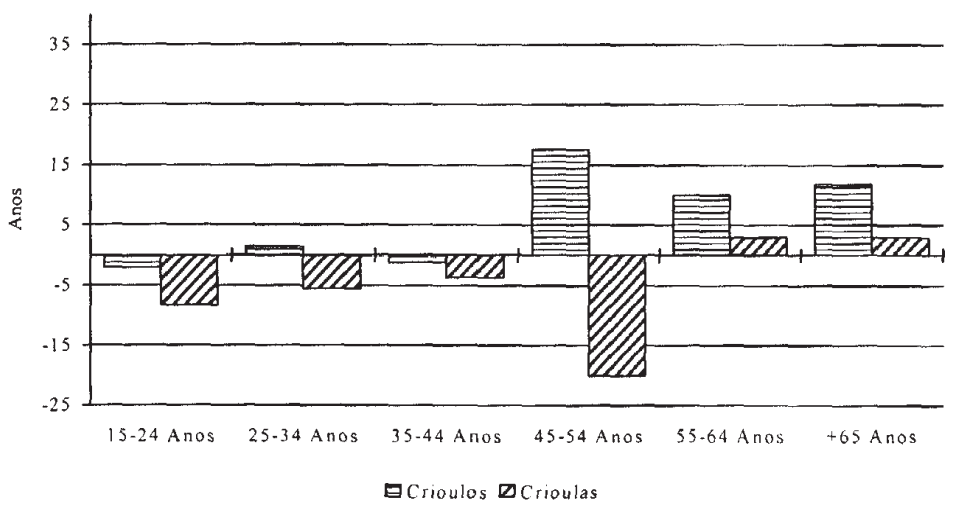

FONTE: Inventários Post-Mortem 1809-1830 (Arquivo Nacional).

Ora, a preeminência dos mais velhos representava a cristalização de um poder político pacificador (uma espécie de poder civil) forte entre os escravos. A sua retração - mesmo que relativa - só podia contribuir para elevar os níveis de tensão na comunidade escrava, mais um elemento a empurrar aos limites as possibilidades da vida em cativeiro. Deve-se, contudo, supor que o incremento do tráfico significava a exacerbação dos mecanismos matrimoniais calcados na força? Que a comunidade escrava vivia então a passagem para um estado social de guerra no qual as mulheres, como regra, eram obtidas por meio da tocaia nos campos? Dificilmente. Um resultado possível, corroborado pelas fontes, era o incremento da rivalidade entre africanos e crioulos. Estes últimos, afinal de contas, perdiam o controle sobre as jovens férteis, o que não era pouca coisa numa comunidade marcada por dolorosos desequilíbrios entre os sexos e paupérrima no que se refere à expectativa de sobressair-se sobre os demais - compreende-se, assim, por que tendiam a se fechar entre si e recusar as uniões mistas. Nossas fontes não são capazes de indicá-los, mas a permanência e a duração da escravidão nos asseguram que a comunidade cativa encontrou outros meios de regrar-se. 


\section{Apêndice}

FLUTUAÇÕES DO VOLUME E DA MORTALIDADE DO TRÁFICO DE ESCRAVOS ENTRE A ÁFRICA E O PORTO DO RIO DE JANEIRO, 1795-1830 (SEM CONTAR AS VIAGENS COM INTENÇÃO DE DESEMBARCAR NO RIO DE JANEIRO)

\begin{tabular}{|c|c|c|c|c|c|c|}
\hline Período & $\begin{array}{l}\text { Porto/Região de } \\
\text { embarque }\end{array}$ & $\begin{array}{c}\# \mathrm{de} \\
\text { viagens }\end{array}$ & \begin{tabular}{|c|}
$\#$ de \\
escravos \\
exporta- \\
dos
\end{tabular} & \begin{tabular}{|c} 
\# de \\
escravos \\
importa- \\
dos
\end{tabular} & \begin{tabular}{|c|}
$\#$ de \\
viagens \\
com mor- \\
talidade \\
\end{tabular} & $\begin{array}{c}\text { Taxa \% } \\
\text { de morta- } \\
\text { lidade }\end{array}$ \\
\hline 1795 & $\begin{array}{l}\text { ÁFRICA CENTRAL } \\
\text { ATLÂNTICA }\end{array}$ & 12 & 5727 & 5383 & 12 & 6,0 \\
\hline 1795 & Luanda & 3 & 1514 & 1324 & 3 & 12,5 \\
\hline 1795 & Benguela & 8 & 3678 & 3571 & 8 & 2,9 \\
\hline 1795 & "Angola" & 1 & 535 & 488 & 1 & 8,8 \\
\hline $1796-1800$ & $\begin{array}{l}\text { ÁFRICA CENTRAL } \\
\text { ATLÂNTICA }\end{array}$ & 106 & 50583 & 46384 & 103 & 8,3 \\
\hline $1796-1800$ & Luanda & 37 & 18793 & 17257 & 36 & 8,2 \\
\hline $1796-1800$ & Benguela & 57 & 26155 & 23892 & 57 & 8,7 \\
\hline $1796-1800$ & "Angola" & 12 & 5635 & 5235 & 10 & 6,9 \\
\hline $1796-1800$ & ÁFRICA ORIENTAL & 3 & 1153 & 950 & 2 & 17,6 \\
\hline $1796-1800$ & "Moçambique" & 3 & 1153 & 950 & 2 & 17,6 \\
\hline $1801-1805$ & $\begin{array}{l}\text { ÁFRICA CENTRAL } \\
\text { ATLÂNTICA }\end{array}$ & 102 & 53196 & 49817 & 102 & 6,4 \\
\hline $1801-1805$ & Luanda & 34 & 18483 & 17019 & 34 & 7,9 \\
\hline $1801-1805$ & Benguela & 59 & 29706 & 28062 & 59 & 5,5 \\
\hline $1801-1805$ & "Angola" & 9 & 5007 & 4736 & 9 & 5,4 \\
\hline $1801-1805$ & ÁFRICA ORIENTAL & 1 & 500 & 340 & 1 & 32,0 \\
\hline $1801-1805$ & "Moçambique" & 1 & 500 & 340 & 1 & 32,0 \\
\hline $1801-1805$ & INDETERMINADO & 1 & 523 & 510 & - & - \\
\hline $1806-1810$ & ÁFRICA OCIDENTAL & 9 & 2299 & 2168 & 5 & 6,1 \\
\hline $1806-1810$ & Bonny & 1 & 277 & 257 & 1 & 7,2 \\
\hline $1806-1810$ & Gabão & 1 & 252 & 237 & - & - \\
\hline $1806-1810$ & Velho Calabar & 2 & 759 & 714 & 1 & 5,7 \\
\hline
\end{tabular}


(continuação)

\begin{tabular}{|c|c|c|c|c|c|c|}
\hline Período & $\begin{array}{l}\text { Porto/Região de } \\
\text { embarque }\end{array}$ & $\begin{array}{c}\# \text { de } \\
\text { viagens }\end{array}$ & $\begin{array}{c}\# \text { de } \\
\text { escravos } \\
\text { exporta- } \\
\text { dos }\end{array}$ & $\begin{array}{c}\# \text { de } \\
\text { escravos } \\
\text { importa- } \\
\text { dos }\end{array}$ & $\begin{array}{c}\# \text { de } \\
\text { viagens } \\
\text { com mor- } \\
\text { talidade }\end{array}$ & $\begin{array}{c}\text { Taxa \% } \\
\text { de morta- } \\
\text { lidade }\end{array}$ \\
\hline $1806-1810$ & Ilha de São Tomé & 4 & 597 & 565 & 2 & 8,9 \\
\hline $1806-1810$ & "Costa da Mina" & 1 & 414 & 395 & 1 & 4,6 \\
\hline $1806-1810$ & $\begin{array}{l}\text { ÁFRICA CENTRAL } \\
\text { ATLÂNTICA }\end{array}$ & 118 & 62589 & 54218 & 108 & 13,5 \\
\hline $1806-1810$ & Molembo & 1 & 529 & 458 & - & - \\
\hline $1806-1810$ & Cabinda & 11 & 5573 & 4981 & 3 & 6,4 \\
\hline $1806-1810$ & Luanda & 15 & 6360 & 5067 & 15 & 20,3 \\
\hline $1806-1810$ & Benguela & 41 & 21616 & 19388 & 40 & 10,2 \\
\hline $1806-1810$ & "Angola" & 50 & 28511 & 24324 & 50 & 14,7 \\
\hline $1806-1810$ & $\begin{array}{l}\text { ÁFRICA } \\
\text { ORIENTAL }\end{array}$ & 7 & 2678 & 2110 & 7 & 21,2 \\
\hline $1806-1810$ & "Moçambique" & 7 & 2678 & 2110 & 7 & 21,2 \\
\hline $1811-1815$ & ÁFRICA OCIDENTAL & 18 & 5705 & 4975 & 14 & 12,8 \\
\hline $1811-1815$ & Ajuda & 1 & 142 & 139 & 1 & 2,1 \\
\hline $1811-1815$ & Costa do Ouro & 3 & 832 & 780 & 3 & 6,2 \\
\hline $1811-1815$ & Bonny & 1 & 516 & 317 & 1 & 38,6 \\
\hline $1811-1815$ & Gabão & 2 & 110 & 107 & 2 & 2,7 \\
\hline $1811-1815$ & Rio Camerum & 4 & 1916 & 1719 & 3 & 9,8 \\
\hline $1811-1815$ & Velho Calabar & 3 & 950 & 856 & 3 & 9,9 \\
\hline $1811-1815$ & Ilha de São Tomé & 2 & 624 & 544 & - & - \\
\hline $1811-1815$ & Ilha do Príncipe & 1 & 212 & 162 & 1 & 23,6 \\
\hline $1811-1815$ & "Costa da Mina" & 1 & 403 & 351 & - & - \\
\hline $1811-1815$ & $\begin{array}{l}\text { ÁFRICA CENTRAL } \\
\text { ATLÂNTICA }\end{array}$ & 182 & 84060 & 78731 & 137 & 6,5 \\
\hline $1811-1815$ & Loango & 1 & 502 & 497 & 1 & 1,0 \\
\hline $1811-1815$ & "Norte do Congo" & 2 & 218 & 218 & - & - \\
\hline $1811-1815$ & Congo & 6 & 2992 & 2910 & 5 & 2,1 \\
\hline $1811-1815$ & Cabinda & 65 & 26601 & 25267 & 49 & 4,9 \\
\hline $1811-1815$ & Ambriz & 1 & 486 & 481 & 1 & 1,0 \\
\hline $1811-1815$ & Luanda & 17 & 8619 & 7784 & 11 & 11,3 \\
\hline $1811-1815$ & Benguela & 42 & 20613 & 19229 & 34 & 6,7 \\
\hline
\end{tabular}


(continuação)

\begin{tabular}{|c|c|c|c|c|c|c|}
\hline Período & $\begin{array}{l}\text { Porto/Região de } \\
\text { embarque }\end{array}$ & $\begin{array}{l}\# \text { de } \\
\text { viagens }\end{array}$ & $\begin{array}{c}\# \text { de } \\
\text { escravos } \\
\text { exporta- } \\
\text { dos }\end{array}$ & $\begin{array}{c}\# \text { de } \\
\text { escravos } \\
\text { importa- } \\
\text { dos }\end{array}$ & \begin{tabular}{|c|}
$\#$ de \\
viagens \\
com mor- \\
talidade
\end{tabular} & $\begin{array}{c}\text { Taxa \% } \\
\text { de morta- } \\
\text { lidade }\end{array}$ \\
\hline $1811-1815$ & "Angola" & 48 & 24029 & 22345 & - & - \\
\hline $1811-1815$ & ÁFRICA ORIENTAL & 21 & 8063 & 6817 & 13 & 14,1 \\
\hline $1811-1815$ & "Moçambique" & 17 & 6938 & 5846 & 11 & 14,2 \\
\hline $1811-1815$ & Quilimane & 1 & 352 & 302 & - & - \\
\hline $1811-1815$ & Inhambane & 2 & 419 & 365 & 2 & 12,9 \\
\hline $1811-1815$ & Madagascar & 1 & 354 & 304 & - & - \\
\hline $1811-1815$ & INDETERMINADO & 2 & 1145 & 921 & - & - \\
\hline $1816-1820$ & ÁFRICA OCIDENTAL & 1 & 386 & 337 & - & - \\
\hline $1816-1820$ & Anomabu & 1 & 386 & 337 & - & - \\
\hline $1816-1820$ & $\begin{array}{l}\text { ÁFRICA CENTRAL } \\
\text { ATLÂNTICA }\end{array}$ & 200 & 86080 & 79983 & 120 & 7,2 \\
\hline $1816-1820$ & Loango & 1 & 476 & 442 & - & - \\
\hline $1816-1820$ & Congo & 6 & 2027 & 1989 & 6 & 1,9 \\
\hline $1816-1820$ & Cabinda & 108 & 43163 & 40038 & 74 & 7,6 \\
\hline $1816-1820$ & Ambriz & 1 & 420 & 390 & - & - \\
\hline $1816-1820$ & Luanda & 34 & 15258 & 14143 & 13 & 7,5 \\
\hline $1816-1820$ & Benguela & 30 & 14293 & 13397 & 15 & 5,6 \\
\hline $1816-1820$ & “Angola" & 20 & 10443 & 9584 & 12 & 8,8 \\
\hline $1816-1820$ & ÁFRICA ORIENTAL & 49 & 25237 & 20013 & 20 & 20,7 \\
\hline $1816-1820$ & "Moçambique" & 24 & 12625 & 10012 & 16 & 20,7 \\
\hline $1816-1820$ & Quilimane & 13 & 6516 & 5165 & 4 & 20,9 \\
\hline $1816-1820$ & Madagascar & 12 & 6096 & 4836 & - & - \\
\hline $1816-1820$ & INDETERMINADO(a) & 1 & 0 & 114 & - & - \\
\hline $1821-1825$ & ÁFRICA OCIDENTAL & 3 & 1240 & 1116 & 2 & 9,6 \\
\hline $1821-1825$ & Lagos & 1 & 408 & 390 & 1 & 4,4 \\
\hline $1821-1825$ & Rio Camerum & 2 & 832 & 726 & 1 & 14,7 \\
\hline $1821-1825$ & $\begin{array}{l}\text { ÁFRICA CENTRAL } \\
\text { ATLÂNTICA }\end{array}$ & 201 & 95164 & 87292 & 179 & 7,2 \\
\hline $1821-1825$ & Molembo & 2 & 628 & 607 & 2 & 3,3 \\
\hline
\end{tabular}


(conclusão)

\begin{tabular}{|c|c|c|c|c|c|c|}
\hline Período & $\begin{array}{l}\text { Porto/Região de } \\
\text { embarque }\end{array}$ & $\begin{array}{c}\# \text { de } \\
\text { viagens }\end{array}$ & $\begin{array}{c}\# \text { de } \\
\text { escravos } \\
\text { exporta- } \\
\text { dos }\end{array}$ & \begin{tabular}{|c|}
$\#$ de \\
escravos \\
importa- \\
dos
\end{tabular} & $\begin{array}{c}\# \text { de } \\
\text { viagens } \\
\text { com mor- } \\
\text { talidade }\end{array}$ & $\begin{array}{c}\text { Taxa \% } \\
\text { de morta- } \\
\text { lidade }\end{array}$ \\
\hline $1821-1825$ & Congo & 2 & 556 & 529 & 1 & 4,0 \\
\hline $1821-1825$ & Cabinda(b) & 47 & 24228 & 21974 & 38 & 5,3 \\
\hline $1821-1825$ & Ambriz & 20 & 9689 & 9373 & 17 & 2,5 \\
\hline $1821-1825$ & Luanda & 19 & 8621 & 7709 & 17 & 10,8 \\
\hline $1821-1825$ & Benguela (c) & 36 & 15831 & 14924 & 32 & 4,8 \\
\hline $1821-1825$ & "Angola" & 75 & 35611 & 32176 & 72 & 9,7 \\
\hline $1821-1825$ & ÁFRICA ORIENTAL & 81 & 39952 & 32087 & 77 & 18,9 \\
\hline $1821-1825$ & “Moçambique"(d ) & 36 & 18529 & 14945 & 34 & 17,7 \\
\hline $1821-1825$ & Quilimane & 45 & 21423 & 17142 & 43 & 20,0 \\
\hline $1821-1825$ & INDETERMINADO & 3 & 1330 & 1238 & - & - \\
\hline $1826-1830$ & ÁFRICA OCIDENTAL & 3 & 1372 & 1312 & - & - \\
\hline $1826-1830$ & Anomabu(i) & 1 & 431 & 430 & - & - \\
\hline $1826-1830$ & Ilha de São Tomé & 1 & 529 & 510 & - & - \\
\hline $1826-1830$ & Ajuda & 1 & 412 & 372 & - & - \\
\hline $1826-1830$ & $\begin{array}{l}\text { ÁFRICA CENTRAL } \\
\text { ATLÂNTICA }\end{array}$ & 411 & 149485 & 139974 & 329 & 5,1 \\
\hline $1826-1830$ & Molembo(g) & 25 & 5143 & 4773 & 17 & 4,1 \\
\hline $1826-1830$ & Congo(h) & 25 & 7760 & 7479 & 20 & 2,3 \\
\hline $1826-1830$ & Cabinda(e) & 113 & 48026 & 44725 & 95 & 3,6 \\
\hline $1826-1830$ & Ambriz(f) & 99 & 22930 & 21968 & 50 & 3,0 \\
\hline $1826-1830$ & Luanda & 10 & 4682 & 4454 & 9 & 4,8 \\
\hline $1826-1830$ & Benguela & 58 & 23580 & 21993 & 58 & 6,7 \\
\hline $1826-1830$ & "Angola" & 81 & 37364 & 34582 & 80 & 7,5 \\
\hline $1826-1830$ & ÁFRICA ORIENTAL & 99 & 57329 & 50653 & 94 & 11,7 \\
\hline $1826-1830$ & "Moçambique" & 48 & 29770 & 25715 & 45 & 13,7 \\
\hline $1826-1830$ & Quilimane & 36 & 18738 & 16768 & 34 & 10,8 \\
\hline $1826-1830$ & Inhambane & 6 & 3601 & 3326 & 6 & 7,6 \\
\hline $1826-1830$ & Lourenço Marques & 7 & 3907 & 3685 & 7 & 5,7 \\
\hline $1826-1830$ & Madagascar & 2 & 1313 & 1159 & 2 & 11,7 \\
\hline $1826-1830$ & INDETERMINADO & 2 & 249 & 229 & - & - \\
\hline
\end{tabular}


(a) não há registro do número de escravos exportados nem do local de embarque.

(b) Inclui nau saqueada por piratas espanhóis em Cabinda (1823), que embarcou 523 escravos, dos quais 260 desembarcaram no Rio de Janeiro; inclui ainda navio negreiro saqueado por piratas americanos em Cabinda (1825), que embarcou 700 escravos, sem registro de desembarque no Rio de Janeiro.

(c) Inclui nau saqueada por piratas em Benguela (1825), que embarcou 301 escravos, dos quais 163 desembarcaram no Rio de Janeiro.

(d) Inclui navio negreiro que embarcara 622 escravos em Moçambique, naufragado em 1825; foram resgatados e desembarcaram no Rio de Janeiro 138 escravos.

(e) Inclui nau saqueada por piratas em Cabinda (1827), que embarcou 498 escravos, dos quais 135 desembarcaram no Rio de Janeiro; outra, roubada em 1828, que embarcou 451 africanos e desembarcou 111 no Rio; mais uma, saqueada em 1828 por piratas de Buenos Aires, que embarcara 424 escravos e conseguiu fazer chegar ao Rio 95; inclui outra viagem de 1828, que depois de embarcar 692 escravos foi saqueada por piratas, mas que conseguiu chegar ao Rio com 131 cativos; inclui ainda viagem que em 1829 foi roubada ainda em terra, na África, mas que mesmo assim conseguira embarcar 292 escravos, fazendo chegar ao Rio de Janeiro 180.

(f) Inclui nau saqueada por piratas em Ambriz (1828), que embarcou 300 escravos, dos quais 213 desembarcaram no Rio de Janeiro; outra, saqueada em 1830, que embarcou 418 escravos e desembarcou 311 no Rio; mais uma, igualmente saqueada em 1830 por piratas, que embarcara 345 escravos e conseguiu fazer chegar ao Rio 213; inclui outra viagem de 1830, que depois de embarcar 423 escravos foi saqueada por piratas, mas que conseguiu chegar ao Rio com 402 cativos.

(g) Inclui nau saqueada em Molembo (1827), que embarcou 266 escravos, dos quais 53 desembarcaram no Rio de Janeiro.

(h) Inclui nau saqueada por piratas em Congo (1828), que embarcou 220 escravos, dos quais 92 desembarcaram no Rio de Janeiro.

(i) Inclui nau saqueada em Anomabu (1828), que ainda assim embarcou 431 escravos, dos quais 430 desembarcaram no Rio de Janeiro.

(j) Para o ano de 1795, a série de viagens se inicia em 5 de julho.

\section{Critérios:}

1. No TSTD2, trabalha-se com a variável majbuyport e, quando esta não existe, utiliza-se a variável plac1tra;

2. Para 1.331 viagens, os registros oferecem o total de escravos exportados (618.910) e o de importados (564.318) - só esta amostragem é trabalhada para se estabelecer os níveis de mortalidade (claro, sem considerar os 6 casos em que há informações sobre estas três variáveis, mas não se conseguiu determinar o porto de embarque 2.574 exportados e 2.238 importados);

3. Um total de 252 viagens não apresenta registro de importações ou de mortalidade ou de exportações ou não oferecem nenhuma dessas informações. Em tais casos: 
3.1. Quando a viagem apresenta informação sobre o total de africanos importados e sobre a mortalidade (6 casos, com 2.915 importados), da soma entre ambos se estabelece o total de exportados;

3.2. Quando a viagem apresenta informação sobre o total de africanos exportados e sobre a mortalidade (4 casos, com 1.803 exportados), da diminuição de um pelo outro se estabelece o total de importados;

3.3. Quando a viagem apresenta informação sobre o total de africanos exportados e importados (37 casos, com 12.120 exportados e 11.816 importados), aceita-se tais números;

3.4. Quando a viagem apresenta informação apenas sobre o total de africanos importados (103 casos, com 44.179 importados), aplica-se a taxa média de mortalidade detectada para a macrorregião africana no quinquênio (ou o mais próximo) e, por meio dela, se estabelece o total de exportados;

3.5. Quando a viagem apresenta informação apenas sobre o total de africanos exportados (12 casos, com 4.824 importados), aplica-se a taxa média de mortalidade detectada para a macrorregião africana no quinquênio (ou o mais próximo) e, por meio dela, se estabelece o total de importados;

3.6. Para viagens que informam apenas o local de embarque (90 casos), aplicam-se médias de exportação, de importação e de mortalidade detectadas para a macrorregião africana no quinquênio (ou o mais próximo);

3.7. Para a única viagem em que o número de exportados (245) é inferior ao de importados (406), aceita-se o total de importados, aplica-se a mortalidade do quinquênio e encontram-se as exportações;

4. Exatas 16 viagens sofreram ataques de piratas, ou foram roubadas ainda em terra na África ou conheceram naufrágios. Em tais casos, aceitaram-se os totais de exportados (6.906) e de importados (2.957).

Recebido em maio de 2009. Aprovado em maio de 2009. 